DIW BERLIN

Discussion

Papers
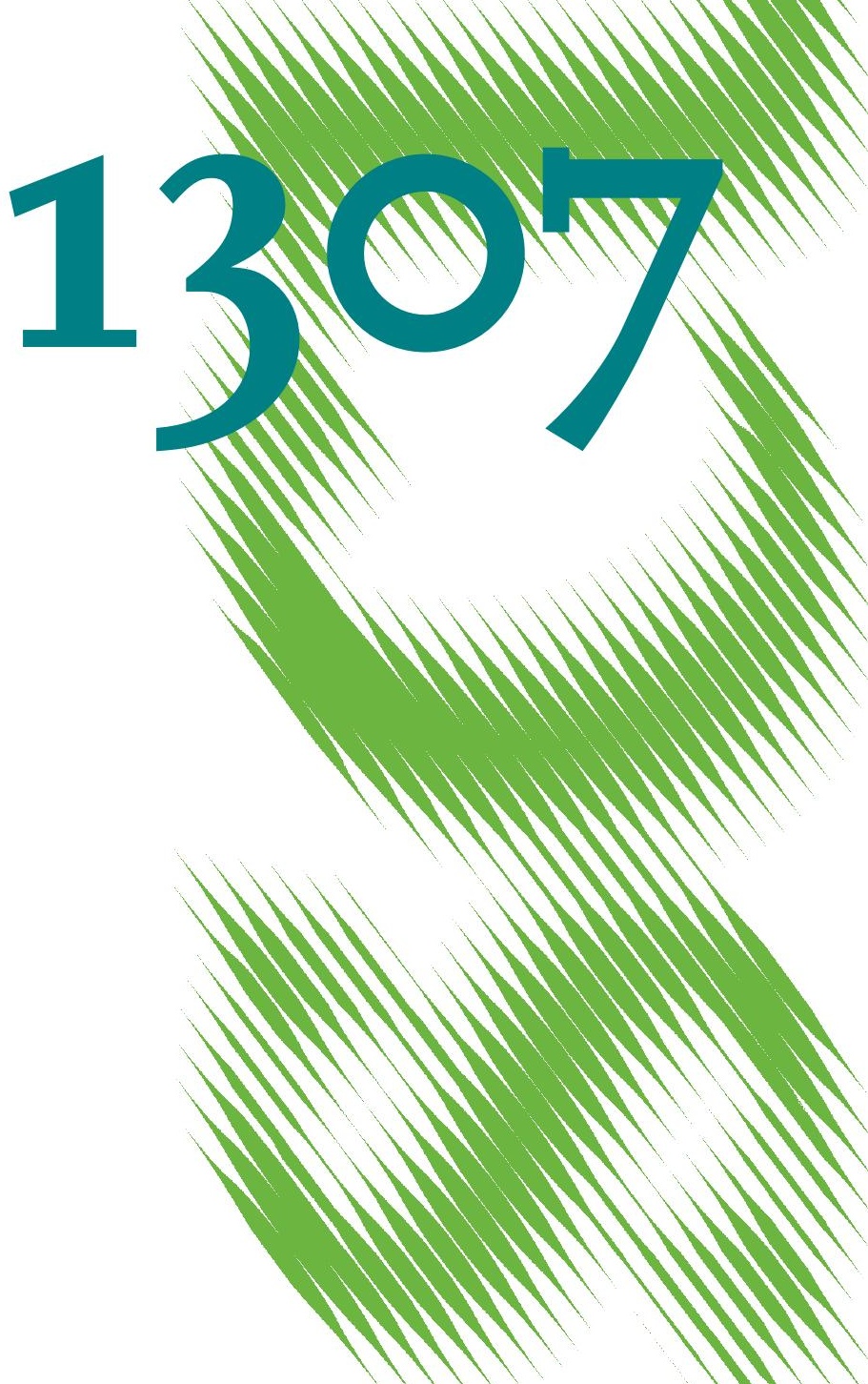

Fiscal Federalism and

Tax Administration

Evidence from Germany 
Opinions expressed in this paper are those of the author(s) and do not necessarily reflect views of the institute.

IMPRESSUM

(C) DIW Berlin, 2013

DIW Berlin

German Institute for Economic Research

Mohrenstr. 58

10117 Berlin

Tel. $+49(30) 89789-0$

Fax +49 (30) $89789-200$

http://www.diw.de

ISSN print edition $1433-0210$

ISSN electronic edition 1619-4535

Papers can be downloaded free of charge from the DIW Berlin website:

http://www.diw.de/discussionpapers

Discussion Papers of DIW Berlin are indexed in RePEc and SSRN:

http://ideas.repec.org/s/diw/diwwpp.html

http://www.ssrn.com/link/DIW-Berlin-German-Inst-Econ-Res.html 


\title{
Fiscal federalism and tax administration - evidence from Germany
}

\author{
Timm Bönke, Beate Jochimsen and Carsten Schröder^
}

June 2013

\begin{abstract}
In many federations, fiscal equalization schemes soften fiscal imbalances across the member states. Such schemes usually imply that the member states internalize only a small fraction of the additional tax revenue from an expansion of the state-specific tax bases, while the remainder of the additional tax revenue is redistributed horizontally or vertically. We address the question as to which extent state-level jurisdictions in such a federation underexploit their tax bases. By means of a stylized model we show that the state authorities in such a federation have incentives to align the effective tax rates of their residents to the internalized fraction of marginal tax revenue. We empirically test the model using three setups: one state level exercise and two micro level exercises using administrative income-tax data in form of an OLS regression and a natural-experiments design. All setups support the results from our theoretical model.
\end{abstract}

JEL-Codes: C21, H21, H77

Key words: fiscal federalism, taxation, tax-back rate, fiscal externalities

\footnotetext{
^ Timm Bönke, Freie Universitaet Berlin, School of Business and Economics; Beate Jochimsen, Department of Economics, Berlin School of Economics and Law, and German Institute for Economic Research; Carsten Schröder, Christian-Albrechts-University of Kiel, Department of Economics, Chair of Public Economics, Social Policy and Health Economics. All correspondence to: timm.boenke@fu-berlin.de. We thank Sebastian Paul and Benjamin Beckers for research assistance and participants in research seminars at the Universities of Muenster and Duisburg-Essen for many helpful comments on earlier drafts of this paper. For the same reason, our thanks go to Johannes Bröcker, Thiess Büttner, Giacomo Corneo, Helmut Herwartz and Sarah Necker.
} 


\section{Introduction}

Fiscal equalization schemes are an important feature of public finance frameworks. Countries that have implemented fiscal equalization schemes include Canada, Switzerland, Australia and Germany. In the United States, an explicit federal equalization scheme for reducing fiscal disparities between the states does not exist. However, certain vertical federal-state transfers, e.g. education programs aimed at the disadvantaged, food and nutrition programs and Medicaid, have an equalizing component.

Theoretical research on the incentives of fiscal equalization schemes and federalism in general has a long tradition. Pioneering works on the assignment of functions to different governmental layers and appropriate fiscal instruments date back to Musgrave (1959) and Oates (1972). The role of inter-regional spillover effects due to mobile tax bases or interregional externalities in the provision of public goods is investigated in Oates (1972), Boadway and Flatters (1982), Inman and Rubinfeld (1992), or Manasse and Schultz (1999). Other scholars investigate asymmetric information over local preferences for public goods (e.g. Cremer et al., 1996; Bucovetsky et al., 1998), over technologies for the provision of public goods (e.g. Boadway et al., 1995; Raff and Wilson, 1997; Caplan et al., 2000; Breuillé and Gary-Bobo, 2007; Akai and Silva, 2009), and over local tax bases (Bordignon et al., 2001).

The present study investigates the relationships between fiscal equalization in a federation and tax enforcement of the member states. Germany serves as our laboratory. The investigation takes advantage of three German particularities. First, Germany's federal system is cooperative: the tariffs of all the fiscally important taxes, the so-called joint taxes, ${ }^{1}$ are set by the central government, and a uniform tax tariff applies in all German states. Second, the enforcement of the tax law is delegated to the states. Third, the fiscal-equalization system implies that marginal tax-back rates on tax revenues collected by a state (TBR) are low (usually less than 25 percent) and can differ substantially across states. The remainder of marginal tax revenue, the marginal rate of loss, is distributed horizontally or vertically. Marginal tax-back rates differ across states and over time, and they are basically exogenous for state governments.

The three particularities of the German system may lead to moral hazard problems at the state level: On the one hand, the states are responsible for and also bear the full costs of tax enforcement (i.e. the endowment of tax offices with personnel and IT). On the other hand,

\footnotetext{
1 'Joint' because the tax revenue is shared by the federal, state, and local level. 
each state internalizes only $T B R$ of marginal tax revenue. ${ }^{2}$ The remainder, $1-T B R$, is a fiscal externality. Several theoretical works have shown that such fiscal externalities result in inefficient state tax policies in terms of overall costs and benefits to society (e.g., Oates, 1999; Bordignon et al., 2001; Traxler and Reutter, 2008).

At first glance, it appears that the uniformity of the tariffs of the joint taxes in Germany prevents the states from reacting to such fiscal externalities. However, as explained above, the states are responsible for the enforcement of the tax law, and a well-defined uniform 'golden' standard guiding the enforcement is lacking. Indeed, the states decide on the endowment of tax offices with personnel and technical equipment. The states decide on the training standards for taxmen and their work procedures (e.g., the fraction of tax returns that is audited). The states also decide on the rules that are applied whenever the tax law is vague.

In the present paper we explore if the internalized marginal tax returns lead to differences in tax enforcement across the states. If so, a uniform tax tariff de jure will not guarantee a uniform tax tariff de facto, resulting in inefficient enforcement activities from the viewpoint of the overall economy (for similar argumentations see Baretti et al., 2002; Mikesell, 2003; Esteller-Moré, 2005; Martinez-Vazquez and Timofeev, 2005; Libman and Feld, 2007). Further, the principle of equal treatment of equals will be jeopardized, undermining the tax moral of the tax payers.

Our first contribution is that we set up a stylized Samuelson (1954) type model that captures the aforementioned three particularities of Germany's tax and federal system. The model reveals that benevolent state-level planners align the effective tax burdens of their taxpayers with the internalized marginal tax revenue $(I M R)$ that can be generated from a taxpayer. The $I M R$ is the product of two variables: the marginal tax rate of a tax unit and the state-specific marginal tax-back rate (TBR). Hence, the $I M R$ reveals how a marginal variation of the tax base of a resident of a particular state alters the tax revenue of the same state. The model shows that the effective tax burden of a given taxpayer will systematically vary with the tax back rate of the state the taxpayer lives in: Provided that the substitution effect dominates the income effect, the effective tax burden of the taxpayer (the enforcement of taxation) will be positively related with $T B R$.

Our second contribution is empirically: We test if internalized marginal tax returns matter for tax enforcement activities of the states. The empirical analysis comprises a state-level and a micro-level approach. The state-level approach investigates if state-wide tax enforcement

\footnotetext{
${ }^{2}$ See Bordignon et al. (2001) for a theoretical examination of the issue of asymmetric information and optimal redistribution among regions of a federation, for Germany-specific peculiarities, also Baretti et al. (2002), Buettner (2006), and Egger et al. (2009).
} 
activities (as captured by the endowment of tax offices) depend on the internalized marginal returns from taxation. The state-level approach has several weaknesses (discussed in Section 4). As an example, it requires assumptions on the tax-collection technology. For this reason, we complement the state-level with a micro-level approach using administrative data on individual income tax returns. In the micro-level approach we investigate whether taxpayers with the same tax-relevant characteristics (i.e., gross market income; tax deductions; marital status; number of children) but resident in different states (with different $T B R$ ) share the same tax burdens. If tax burdens systematically differ across states, this is an immediate indication of differences in tax enforcement activities. The tests are performed by means of a regression and a difference-in-differences approach. Results from both approaches support the model's implication: the higher the internalized returns from taxation, the higher the level of tax enforcement.

The interplay between fiscal equalization and taxation has also been addressed in earlier literatures. Most of this literature deals with fiscal equalization and locally-decided taxes. Related studies for Germany are Buettner (2006) and Egger et al. (2009). Our research question, however, is different, namely how fiscal equalization impacts states' tax enforcement under a uniform tax law. We are aware of only two studies dealing with this nexus. One study is Traxler and Reutter (2008). It provides a theoretical analysis, but not an empirical examination. Another study is Baretti et al. (2002). It provides a theoretical analysis, and some indirect empirical evidence. None of the studies provides a direct econometric analysis on the interplay between fiscal equalization and tax enforcement. The present paper fills this gap in the literature.

The remainder of the paper is organized as follows. Section 2 briefly introduces Germany’s federal system and the income-tax law. Section 3 presents our theoretical model. Our database is described in Section 4. Section 5 provides the econometric analysis. Finally, Chapter 6 offers some concluding remarks.

\section{Federalism in Germany}

\subsection{The fiscal-equalization system}

Germany's federal structure is reflected by three governmental layers: the federal layer (Bund), the state layer (Bundesländer), and the local layer (Gemeinde). Since the German reunification in 1990, sixteen Laender form the state layer and about 11,500 municipalities the local layer. 
Germany's federal system is cooperative: all the fiscally important taxes are set by the central government, and redistributive horizontal and vertical transfers mitigate regional fiscal imbalances so that regional levels of public goods and services are similar (Art. 107, Para. 2, 1, German Federal Constitution). Essentially, transfers are channeled from relatively wealthy states to poorer ones. The level of the transfer depends on the state-specific "fiscal capacity" and "fiscal needs." Basically, fiscal capacity is determined by tax return per inhabitant (before equalization); fiscal needs by average tax return per inhabitant over all the 16 states.

Total tax revenue of a state originates from two sources: the so-called own-source taxes and the joint taxes. Own-source taxes are administered and collected by the states (or municipalities), and the generated tax revenue exclusively benefits the state (or municipality). Inheritance, property acquisition, and lottery taxes are examples for own-source taxes. Revenues from own-source taxes, however, contribute only a small fraction to total tax revenue. The joint taxes (income, corporation and value added tax) contribute the dominant fraction. In year 2011, for example, the joint taxes made up about 70 percent of total tax revenue. ${ }^{3}$ The common characteristic of the joint taxes is that the tax revenue is shared among the three federal layers. A four-stage equalization system, overviewed in Table 1, assigns the joint taxes to the three layers: ${ }^{4}$

1. Initial assignment of joint taxes by means of politically determined division rules.

2. Horizontal redistribution of up to 25 percent of state-specific revenues from value added taxes (VAT). The aim of the VAT redistribution (Umsatzsteuervorwegausgleich) is to ensure that each state receives at least 92 percent of average per capita tax revenue of all states (mainly the states' shares of income and corporate taxes and some state taxes).

3. Horizontal redistribution of fiscal revenues from financially strong states to financially weak states. A state’s payments/transfers depend on deviations of its fiscal revenue per (virtual) ${ }^{5}$ capita and average fiscal revenue per capita over all states. Fiscal revenues of a state covers its share of income and value added tax, revenues from pure state taxes like inheritance or beer tax and 50 percent of the

\footnotetext{
${ }^{3}$ From the remaining 30 percent, 17 percent of the revenue account for the federal layer. Federal taxes include energy taxes, motor vehicle taxes, various consumer taxes (e.g., tobacco, alcohol and insurance taxes) and the solidarity surcharge. Roughly some two percent of total tax revenue is state taxes. The remaining nine percent account for the local level in form of property, business and some local consumption taxes (Federal Ministry of Finance, 2012).

${ }^{4}$ The equalization system partly changed from 2005 onwards. As our data are only available up to 2004 we describe the equalization system valid at that time. However the main mechanisms remained in place.

${ }^{5}$ For some states with specific financial burdens, population size is adjusted by particular weighting factors.
} 
most important local taxes' (i.e. local business tax and property tax). The aim of the third stage ("Finanzausgleich im engeren Sinne") is to ensure that each state receives at least 95 percent of the average (per capita) fiscal revenue.

4. Vertical transfers from the federal to the state level. The aim of the vertical transfers ("Fehlbetragsbundesergänzungszuweisungen") is to improve the financial situation of those states whose fiscal revenue after stages 1 to 3 still falls below the inter-state average. The grants are uncommitted and cover at least 90 percent of the remaining gap between fiscal revenue and fiscal need. Accordingly, all states effectively end up with at least 99.5 percent of average per capita fiscal revenue.

In addition, special needs grants (Sonderbedarfsbundesergänzungszuweisungen) compensate for special fiscal burdens some states have to bear. These grants are given lump-sum, regardless of fiscal or economic performance.

\section{Table 1 about here}

Germany's four-stage fiscal equalization system drives a substantial wedge between states' tax revenue before and after fiscal equalization. At the margin, state-specific tax-back rates on state tax revenues (TBR) are usually less than 25 percent. The remainder, the marginal rate of loss $(1-T B R)$, is redistributed horizontally or vertically. Due to the complexity of the legal rules of the fiscal-equalization system, it is not feasible to express $T B R$ by means of a simple closed form, say as a function of tax revenue, type of tax revenue, and number of inhabitants. All variations of such and other determinants precipitate themselves in stages 2 to 4 of the transfer system (also Baretti et al., 2002, p. 646). ${ }^{6}$

Because official data on state-specific $T B R$ s are not available we have set up a simulation model of Germany's fiscal equalization system to compute the numbers. ${ }^{7}$ The model takes account of all the regulations codified in Germany's fiscal equalization law relevant for determining the state-specific $T B R$ s at different points in time. The data for our model are official state-level statistics provided by Germany's Federal Statistical Office on the number of inhabitants, tax revenues, etc.. With the model, we can simulate $T B R$ for marginal variations of state-specific income tax revenue. ${ }^{8}$

\footnotetext{
${ }^{6}$ Appendix 1 in Baretti et al. (2002) for details.

${ }^{7}$ Information on the simulations can be provided by the authors upon request.

${ }^{8} T B R$ is the same for a marginal change in income and corporate tax revenue, while it can be different for other types of taxes.
} 
The state-specific TBRs from our simulations are summarized in Table 2. ${ }^{9}$ Results are assembled in three columns. Each column relates to a particular year. The selection of the years is guided by the micro-level income tax data, available for the assessment years 1998, 2001, and 2004. TBRs are low, usually below 25 percent. Further, TBRs vary markedly across states. Interestingly, the relationship between a state's $T B R$ and its fiscal capacity is highly non-linear, not even one-directional. For example, in 1998 the TBR of a 'poor' net-recipient state like the Saarland and a 'rich' net-contributor state are almost the same. This is for the following reason: for net contributor states, $T B R$ reflects that higher tax revenue implies higher payment obligations; for net recipient states, $T B R$ reflects that higher tax revenue implies lower transfer entitlements. ${ }^{10}$ Finally, TBRs for thirteen states exhibit hardly any variation over time, while it varies markedly for three states: Schleswig-Holstein, Bavaria, and Hamburg, with Schleswig-Holstein being the most remarkable case: in 1998, SchleswigHolstein's TBR was exceptionally high (about 57 percent). This is because of a particular constellation: In the same year, Schleswig-Holstein's fiscal capacity almost coincided with the average capacity over all states. As a result, Schleswig-Holstein's horizontal net transfer was close to zero, and its $T B R$ thus equals the initial assignment rule of the joint taxes (stage 1). ${ }^{11}$ Accordingly, we have two groups of states: one group of 13 states where the incentives due to $T B R$ for tax enforcement remained stable over time; another group of three states where these incentives changed over time. This classification can serve as the basis for a natural experiment.

\section{Table 2 about here}

Inter-temporal variations of the $T B R$ of a particular state basically mirrors how the state's fiscal capacity changes relative to the fiscal capacity of all the other 15 states. If a state's fiscal capacity equals the average capacity over all the states, $T B R$ is the highest (like in Schleswig-Holstein in 1998). Any deviation of a state's fiscal capacity from the average fiscal capacity implies that $T B R$ falls sharply. This can be seen from Figures 1a-c, each Figure relating to one of the three observation periods 1998, 2001, and 2004. Within each Figure, sixteen graphs are provided, one for each state. Each graph plots $T B R$ against state per-capita

\footnotetext{
${ }^{9}$ For selected years, we can cross-check the TBRs from our simulations with $T B R$ s from previous literatures (Lichtblau and Huber, 2000; Baretti et al., 2002): TBRs from ours and their simulations coincide.

${ }^{10}$ Plachta (2008) provides a detailed description of the German financial constitution.

${ }^{11}$ The sharp rise of Schleswig-Holstein's marginal rate of loss $(1-T B R)$ in 1998 is also documented in Lichtblau and Huber (2000). Simulations for marginal rate of loss instead of $T B R$ are also provided in Bönke et al. (2011).
} 
income tax revenue (before fiscal redistribution rules are applied). An abscissa value of "0" indicates the actual income tax revenue in the state at the particular point in time. So, the ordinate gives the actual TBR. Moving from the " 0 "-threshold to the right (left) indicates that per capita income tax revenue in the state is fictitiously increased (decreased) by a particular amount. Such a change in per capita income tax revenue changes the fiscal capacity of the respective state relative to the other states, and thus its $T B R$. The graphs convey another important result for our empirical analysis: $T B R$ exhibit non-trivial discontinuities and changes little for reasonable variations of per-capita tax revenue. ${ }^{12}$ It appears as basically impossible for a state to consciously steer $T B R$. Accordingly, we view $T B R$ as an exogenous variable and as a yardstick against which the tax declarations are audited. The interpretation of $T B R$ as an exogenous is further justified for the reason that the $T B R$ of a particular year is always determined before the tax declarations for the same year are audited. This is because horizontal and vertical transfers in a particular year, say assessment year 1998, hinge upon cash tax revenues. Income tax declarations from 1998, however, are handled by the tax authorities as off spring 1999.

\section{Figures 1a-1c about here}

\subsection{The process of income taxation}

The legislation of joint taxes and the responsibility concerning the enforcement of the income tax law are assigned to different governmental layers. The tax-setting autonomy is allocated at the central level. Particularly, the central level defines both tax-tariffs and tax bases, while the states have no tax setting autonomy - even if pure state taxes are concerned. ${ }^{13}$ Accordingly, the states' possibilities to steer income tax revenues and effective income tax burdens of their residents directly are heavily restricted. The responsibility of tax enforcement, however, is delegated to the states.

The de-central settlement of tax enforcement responsibility at the state-level and the monocracy of state financial executives open up opportunities for a politically motivated practice of tax laws. This is because only basic standards guide the tax enforcement activities of the states. Effectively, the state governments decide on the endowment of tax collecting agencies with personnel and IT, or on the training of taxmen. The state governments also give internal instructions providing the taxmen with guidelines how to deal with particular vague

\footnotetext{
${ }^{12}$ Only when a state's fiscal capacity, by coincidence, is rather close to the interstate average, realistic variations of income tax revenue have a profound impact on $T B R$.

${ }^{13}$ Except the rate of the property acquisition tax that can be determined by the states since 2006.
} 
paragraphs in the income tax law. Indeed, a report of the Federal Audit Office (2006, p. 78f.) remarks: "some countries give the impression that the hiring of tax auditors is not interesting due to fiscal equalization; net contributor states had to pay the dominant part of eventual additional tax revenue in the fiscal equalization system, while transfers were reduced for the net recipient state.” In a summarizing statement of the same report it is argued that differences in the personnel endowments of tax offices undermine the "uniformity of taxation in Germany” (Federal Audit Office, 2006, p. 122).

Further indications of a politically motivated tax practice have been provided in previous literature:

1. Vogel $(2000,128-155)$ as well as Schick (2011) find systematic differences in tax revenue per audit and state specific tax auditing frequencies. In the city state ${ }^{14}$ Hamburg, for example, many income millionaires are resident. The auditing rate of these millionaires' income tax returns, however, is substantially lower than in other states (Schick, 2011).

2. A report of the Federal Audit Office (2006, p. 13) documents that in a random sample of 21 tax offices the number of tax audits per taxman and year varies between 972 and 2,720. It is also documented that the complete and equal auditing of tax declarations is no longer secured, and that systematic errors are made in the audits of special expenses in Hamburg (p. 35f.). According to the Audit Office of Berlin (2001), tax returns of employees are not audited with sufficient care, and taxmen refrain from a careful consideration of tax declarations in order to meet thresholds regarding the number of daily audits.

3. To harmonize tax audits, recently a risk management system has been implemented in all tax offices. The system evaluates roughly 2,500 positions in income tax returns, and indicates potential incongruities between the positions. Harmonization was not achieved, because the states modified the detection algorithms independently, and because tax offices responded differently to potential incongruities (Federal Audit Office, 2009, p. 176-179; Federal Audit Office 2012, p. 30). If the system selects a tax return for special audit, it is not secured that this auditing is appropriately conducted. Instead, according to several State Audit Offices, the error rate rates from 12 percent (North Rhine Westphalia) to 52 percent (Brandenburg).

\footnotetext{
${ }^{14}$ Three German cities (Berlin, Bremen, Hamburg) are also independent federal states.
} 
4. Vogel (2000) provides evidence that certain tax payers had been treated preferentially by the states. Examples include generous interpretation of amortization rules or the postponement of tax payments.

In sum, the states bear the full costs related to the enforcement of the income tax law (e.g., related to the endowment of tax offices), but they internalize only part of the resulting tax revenues (due to the redistributive fiscal equalization scheme). Due to the decentralized administration, the means of the central level to control the tax collection process are limited. So the states have both the opportunity and the incentive to align tax enforcement activities with their own objectives, and in this respect $T B R$ may play a prominent role. As outlined above, several state-level indicators suggest differences in state-specific tax enforcement levels. However, the empirical evidence is basically anecdotic and also lacks a rigorous econometric testing.

\section{A stylized model}

Our model relies on Samuelson's (1954) static public good model. Consider a country with $j=1, \ldots, J$ federal states and let a state $j$ have three sources of revenues: income-tax revenue, ${ }^{15}$ equalizing grants, and lump sum transfers, feasible for the provision of a state-wide public good provided at the level $g_{j}$. Transfer rules determining the equalizing grants, $Z_{j}$, and the lump sum transfers $\bar{B}_{j}$, and also the tax tariff, $\tau$, are set by a central planner (whose goal might be the maximization of overall societal welfare). These rules, characterized by $\left[\tau,\left(Z_{1}, \ldots Z_{J}\right),\left(\bar{B}_{1}, \ldots \bar{B}_{J}\right)\right]$, are decided before taxes have actually been collected, and before public goods have been provided. Consistent with the situation in Germany we assume that tax enforcement is delegated to the federal states who interpret $\left[\tau,\left(Z_{1}, \ldots Z_{J}\right),\left(\bar{B}_{1}, \ldots \bar{B}_{J}\right)\right]$ as exogenous (henceforth indicated by vertical bars). We further assume that the tax units resident in a state $j, i_{j}=1, \ldots I_{j}$, are immobile (and so are the incomes, tax bases). ${ }^{16}$

Using the public good as the numéraire, in a static one-period model the public budget constraint of state $j=1$ is given by,

$$
g_{1} \leq T_{1}+Z_{1}+\bar{B}_{1}
$$

with

\footnotetext{
${ }^{15}$ We abstain from modeling other tax types or the possibility of public debt to keep the analysis simple. The reasons and incentives for raising public debt are discussed in Jochimsen and Nuscheler (2011).

${ }^{16}$ The assumption that citizens do not change residences across state borders as response to moderate differences in effective income tax rates is supported by a recent empirical study for Switzerland (see Liebig et al., 2007).
} 


$$
T_{1}=\sum_{i_{1}=1}^{I_{1}} \bar{r} \cdot t_{i_{1}}\left(\tau, y_{i_{1}}, \Delta_{i_{1}}\right),
$$

where $T_{1}$ denotes income tax revenue after the initial assignment of taxes according to division rules in stage 1 of Germany's fiscal equalization system. The term $\bar{r} \approx 0.575$ gives the share from income tax revenue assigned to the state level (including the state's municipalities), and $t_{i_{1}}\left(\tau, y_{i_{1}}, \Delta_{i_{1}}\right)$ is the effective tax burden imposed on tax unit $i_{1}$. The effective tax burden of $i_{1}$ hinges on the progressive tax tariff, $\tau$, on $i_{1}$ 's gross taxable income, $y_{i_{1}}$, and the level of granted deductions, $\Delta_{i_{1}}$. We assume that gross taxable income is exogenous from the taxman's point of view.

The second term in the state's budget constraint is the net equalizing transfers,

$$
Z_{1}=Z_{1}\left[\left(T_{1}(\cdot), I_{1}\right),\left(T_{2}(\cdot), I_{2}\right), \ldots,\left(T_{J}(\cdot), I_{J}\right), \bar{F}\right] .
$$

For net-recipient (net-contributor) states, i.e. for states with a below-average (above-average) per-capita fiscal capacity, the net equalizing transfer is positive (negative). $\bar{F}$ accounts for further particular regulations inherent in Germany's fiscal equalization system. Across the states, equalizing transfers add up to zero, i.e.,

$$
\sum_{j=1}^{J} Z_{j}=0 .
$$

The third term in the state's budget constraint (1), $\bar{B}_{1}$ are lump sum vertical transfers, i.e. special needs grants.

For a tax unit, we assume that preferences are characterized by an additive utility function of the form,

$$
u_{i_{1}}=c_{i_{1}}+h\left(g_{j}\right)
$$

with $c_{i_{1}}$ denoting the level of a private good, the numéraire, and with $g_{1}$ denoting the level of a state-level public good. Accordingly, we abstain from modeling public good spillover effects. The budget constraint of a tax unit is,

$$
c_{i_{1}} \leq y_{i_{1}}-t_{i_{1}}\left(\bar{\tau}, y_{i_{1}}, \Delta_{i_{1}}\right) \text {. }
$$

Suppose $\left[\tau,\left(Z_{1}, \ldots Z_{J}\right),\left(\bar{B}_{1}, \ldots \bar{B}_{J}\right)\right]$ and an interior solution exists. Further, suppose state planners “act as benevolent maximiser of their citizens' welfare” (Edwards and Keen, 1995, p. 113). Finally suppose the citizens' welfare in state 1 (and the other states) is described by a Bentham social welfare function, $W_{1}=\sum_{i_{1}=1}^{I_{1}} u_{i_{1}}$. The optimization problem of a state planner is, 


$$
\begin{aligned}
L_{1}=\sum_{i_{1}=1}^{I_{1}}\left(y_{i_{1}}-\right. & \left.t_{i_{1}}\left(\tau, y_{i_{1}}, \Delta_{i_{1}}\right)+h\left(g_{1}\right)\right) \\
& +\lambda\left[g_{1}-\bar{r} \sum_{i_{1}=1}^{I_{1}} t_{i_{1}}\left(\tau, y_{i_{1}}, \Delta_{i_{1}}\right)+\sum_{k \neq 1} Z_{k}(\cdot)-\bar{B}_{1}\right]
\end{aligned}
$$

The solution is,

$$
\begin{gathered}
\frac{I_{1} \cdot \frac{\partial h}{\partial g_{1}}}{\frac{\partial t_{i_{1}}(\cdot)}{\partial \Delta_{i_{1}}}}=\left[\bar{r} \frac{\partial t_{i_{1}}(\cdot)}{\partial \Delta_{i_{1}}}-\sum_{k \neq 1} \frac{\partial Z_{k}}{\partial T_{1}} \cdot \frac{\partial T_{1}}{\partial t_{i_{1}}(\cdot)} \cdot \frac{\partial t_{i_{1}}(\cdot)}{\partial \Delta_{i_{1}}}\right]^{-1} \quad \forall i_{1}=1, \ldots, I_{1} \\
\Leftrightarrow I_{1} \cdot \frac{\partial h}{\partial g_{1}^{*}}=\left[\bar{r}-\sum_{k \neq 1} \frac{\partial Z_{k}}{\partial t_{i_{1}}\left(\cdot, \Delta_{i_{1}}\right)}\right]^{-1} \quad \forall i_{1}=1, \ldots, I_{1}
\end{gathered}
$$

The benevolent planner in state " 1 " choses $\left(\Delta_{i_{1}}^{*}, \ldots, \Delta_{I_{1}}^{*}, g_{1}^{*}\right)$ so that the optimality condition (8) holds. The optimality condition is a modification of the standard Samuelson condition for the provision of public goods.

Let us consider first the left hand side. The numerator of the term on the left hand side is the sum of the marginal utilities from the provision of one more unit of the state-level public good. The denominator is the change in utility resulting from a marginal change in the tax deductions granted to taxpayer $i_{1}$. The denominator again hinges on the marginal tax rate that increases in taxable income of the particular taxpayer.

Let us second consider the right hand side. The expression in brackets is the effect of a marginal variation of the tax base of resident $i_{1}, \Delta_{i_{1}}$, on the public budget of state "1:" the internalized marginal tax revenue, $I M R_{i_{1}}$. The $I M R_{i_{1}}$ comprises two terms. The first termgives the additional tax revenue resulting from a marginal tax-base variation that is not vertically redistributed: the product of the marginal tax rate, $\partial t_{i_{1}} / \partial \Delta_{i_{1}}$, times the income tax share assigned to the state level, $\bar{r} \approx 0.575$. However, state 1 can internalize only part of this amount. The remainder, $\sum_{k \neq 1} \frac{\partial Z_{k}}{\partial T_{1}} \cdot \frac{\partial T_{1}}{\partial t_{i_{1}}(\cdot)} \cdot \frac{\partial t_{i_{1}}(\cdot)}{\partial \Delta_{i_{1}}}>0$, constitutes a positive fiscal externality for the other 15 states.

Notice that the concept of $I M R_{i_{1}}=T B R \cdot \frac{\partial t_{i_{1}}(\cdot)}{\partial \Delta_{i_{1}}}$ is related to the concept of the tax back rate, $T B R_{1}=\bar{r}-\sum_{k \neq 1} \frac{\partial Z_{k}}{\partial T_{1}}$. However, only the $I M R_{i_{1}}$ reflects that the marginal internalized return from a marginal expansion of the tax base (by granting less tax deductions to tax unit $i_{1}$ ) 
depends on a state-level and a micro-level component: the state's tax-back and the marginal tax rate of the taxpayer whose tax base is expanded.

Equation (8) has immediate implications for the optimal level of deductions, $\Delta_{j}^{*}=\sum_{i_{j}=1}^{I_{j}} \Delta_{i_{j}}^{*}$, from the viewpoint of the benevolent planner in state $j$. Suppose two taxpayers with identical tax-relevant characteristics living in two states 1 and 2 , taxpayers $1_{1}$ and $1_{2}$. Further suppose states' tax-back rates differ, $T B R_{1}>T B R_{2}$. Under ceteris paribus conditions, condition (8) implies that then the level of tax deductions granted to taxpayer $1_{1}$ should be lower than for taxpayer $1_{2}$. This is because the internalized returns from tax enforcement are higher in state 1 compared to state $2 .{ }^{17}$ For example, the states can steer the effective tax burdens by the fraction of tax returns that is audited, or by the 'generosity' of the taxmen concerning the granting of tax deductions.

Equation (8) also indicates that the state planner does not consider the effect of tax enforcement on the budgets of the other states: Every variation of granted tax deductions alters the state's tax revenue ex ante to fiscal equalization, and thus the revenues of all other states. This fiscal externality implies an inefficient level of tax enforcement in terms of overall costs and benefits to society. The following empirical sections challenge equation (8) with empirical evidence.

\section{Database and key figures}

\subsection{Germany’s “Factually Anonymous Income Tax Statistic”}

Germany's Income Tax Statistic (Lohn- und Einkommensteuerstatistik) provides income-tax returns from about 30 million tax units per assessment year. It conveys information on taxable income, family situation, income sources, granted deductions and exemptions, revenues and sources of revenues, income tax burden, etc. From all the tax units, a 10 percent stratified random sample is made available for scientific purposes, the so-called Factually Anonymous Income Tax Statistic (Faktisch anonymisierte Lohn- und Einkommensteuerstatistik, FAST). As the amount of observations is - with annually roughly 3 million tax units - rather high we assume that the data are representative both for the national and for the state level.

FAST is provided in form of three cross-sectional scientific-use-files, covering data for the assessment years 1998, 2001, and 2004. These three cross sections form our database. Unfortunately, more recent data are not available. This is for two reasons. First, tax units have

\footnotetext{
${ }^{17}$ The argumentation requires that the substitution effect always dominates the income effect. It must also be ensured that variations of discretionary deductions and corresponding changes in income tax revenue have at most a small effect on TBR. As Figures 1a-c indicated, this is not a too strong assumption. As pointed out in Section 2.1, in the empirical examination $T B R$ are indeed exogenous.
} 
an extensive period to file their income tax statements before the statements are audited and processed by the tax collecting authority. For complex income tax statements the whole process can easily take up to five years. Second, once the taxation process is completed, the data must be assembled by the state statistical offices and forwarded to the federal statistical office, where the scientific use files are prepared.

FAST allows the identification of all relevant steps from gross taxable income $\left(y_{i}\right)$ to the actual tax base on which the income tax liability is calculated. The difference between $y_{i}$ and the actual tax base is the sum of all granted deductions $\left(\Delta_{i}\right)$ and serves as our measure of effective tax administration. The idea is the following. If the tax unit is risk averse it will declare all relevant incomes to the tax authorities. These reported incomes serve as our gross taxable income, $y_{i}$, and is exogenous from the taxman's point of view. To reduce its tax burden, the tax unit will try to claim as many deductions from the gross taxable income as possible and the taxman will either grant them or not. While we cannot observe if all the claimed deductions are granted we can observe the actual deduction as difference between gross taxable income and the fixed tax base, hence our measure $\Delta_{i}$. If we effectively control for all the relevant characteristics (which are provided in our data) the level of granted deduction $\Delta_{i}$ should not systematically vary between states. However, systematic differences may occur mainly due to two reasons: First, when granting deduction the taxman may have a margin of discretion. Theses discretionary deductions are subject to vague legal terms ("unbestimmte Rechtsbegriffe"). Accordingly, the taxmen have some discretion regarding the interpretation of the case-relevant characteristics that determine the granted deduction (for a detailed discussion see Vogel, 2000, p. 73-75). For example, the level of expenses exceeding blanket allowances and qualified as deductible, despite some guidelines, is a decision $e x$ aequo et bono of the auditing taxman. ${ }^{18}$ Second, due to a number of reasons the effectiveness of tax audits may differ systematically across states. One result may be that deduction, even if they are non-discretionary, meaning that there are granted lump sum and are based on automatisms following well-defined legal terms ("bestimmter Rechtsbegriff”), are granted by mistake (e. g. Federal Audit Office, 2006; Audit Office of Berlin, 2001). These assessment errors may for example be correlated with the staffing of the financial administration or the characteristics of the risk management deployed and vary systematically across states. Therefore, total granted deductions can serve as a measure how strict tax returns are audited by the local taxman.

\footnotetext{
${ }^{18}$ An overview of norms in the German income tax code that incorporate vague legal terms is provided in Bönke et al. (2011), Table A1 in the Appendix.
} 


\subsection{Descriptive figures from income tax statistics}

Figures 2a-c give the state- and period specific distributions of effective internalized marginal revenues $\left(I M R_{i_{j}}\right)$. Each figure comprises sixteen graphs. In each graph, a state specific distribution of IMR (solid line) is benchmarked against the German average (dashed line). The differences between the two distributions mirror differences in the state-specific income distributions and TBRs.

\section{Figures 2a-2c about here}

In order to compare the concept of $I M R_{i_{j}}$ and $T B R_{j}$, Table 3 provides state-wide average for years 1998, 2001 and 2004 of $I M R_{i_{j}}$, $a v_{j}\left(I M R_{i_{j}}\right)=\frac{1}{I_{j, y e a r}} \sum_{i_{j, y e a r}=1}^{I_{j, y e a r}} I M R_{i_{j, y e a r}}$ : the average of the individual marginal tax rates of the residents in a state (as provided in Table A1) times the state's $T B R_{j}$ (provided in Table 2). The higher is $a v_{j}\left(I M R_{i_{j}}\right)$, the higher is the internalized revenue and the incentive to secure an effective tax enforcement. As can be seen from Table 3, $a v_{j}\left(I M R_{i_{j}}\right)$ differ substantially across states, ranging from 1.85 percent in 2004 in Mecklenburg-Western Pomerania to 17.65 percent in Schleswig-Holstein in 1998. They also change over time. This is mainly for tworeasons: changes in tax back rates and changes in marginal tax rates. Changes in the marginal tax rates again have two predominant causes: shifts in the distributions of tax-relevant characteristics (especially taxable income) and income tax reforms altering marginal tax rates. Indeed, the income tax law has been changed during the observation period. Particularly, the marginal tax rate for the top income bracket has been lowered form 53 in 1998 to 45 percent in 2004.

\section{Table 3 about here}

Further descriptive statistics of FAST variables used in adjacent regression analyses are summarized in Table A1 in the Appendix. By year and state, the table provides means and standard deviations of the gross taxable income before any deductions, $y_{i_{j}}$, and total deductions defined as the difference between gross taxable income and the actual fixed tax base, $\Delta_{i_{j}}$. All monetary amounts are expressed in year 2004 prices. The table also gives the mean marginal tax rates and the number of weighted and non-weighted observations. Due to 
the factual anonymisation information on the process of taxation and state of residency is incomplete for several tax units, particularly for very rich ones. These units had to be discarded from the database, leaving us with a pooled sample of roughly six million observations (two million per cross section).

Gross taxable income before any deductions is the central micro-level conditioning variable in the empirical analysis. It has a profound impact on the level of deductions, and it is exogenous from the viewpoint of states' taxmen. Across the states, average gross taxable income is the highest for Baden-Wurttemberg and Hesse, and the lowest in Thuringia. Over time, average price adjusted gross taxable incomes varies only little.

Granted tax deductions is the central endogenous variable in the empirical analysis. Averages deductions for tax units in year 1998, for example, range between $€ 5,466$ (Brandenburg) and $€ 7,186$ (Baden-Wurttemberg). It is, however, not necessarily true that deductions are higher in richer than in poorer states. As an example, in 2004 average gross taxable income in Bavaria is about $€ 1,500$ lower than in Hesse, but average deductions in Bavaria are about $€ 140$ higher.

\section{Econometric analysis}

\subsection{Regressions using state-level variables}

We start our analysis with a "macro-econometric" model using state-level aggregates in the spirit of studies such as Baretti et al (2002). The basic idea of such a model is to econometrically explain the state-wide level of tax enforcement by $T B R$, after controlling for other state-level variables. Particularly, we measure tax enforcement by an input variable, the staffing of tax offices: the state-wide number of income tax returns divided by the number of full time equivalent employees in the financial administration. The smaller the ratio, so the argument, the better the endowment of the tax offices, and the higher is the enforcement level. The state-level approach has two central weaknesses. First, economies of scale in tax administration are not well understood. In the presence of increasing returns to scale, highly populated states might enforce the tax law more effectively with the same staffing of tax offices compared to low populated states. Second, the approach does not control for differences in the distributions of individual IMRs across states (but uses a state-wide indicator). However, equation (8) indicates that the distribution of $I M R$ s across a state's tax payers matters for tax enforcement. For these two reasons, results from a state-level regression approach should be viewed only as a preliminary naïve attempt to study the incentives of Germany’s federal system on the tax policies of the states. 
We implement two state-level panel regressions. In both regressions, the dependent variable is the inter-temporal change in the staffing of tax offices: the number of income tax returns divided by the number of full time equivalent employees in the financial administration. Staffing is available to us for the years 1998, 2001 and 2004. As staffing will respond to changes in tax enforcement incentives with some delay, the inter-temporal change in staffing in state $j$ is: $\Delta$ staffing $_{j}=$ staffing $_{j, 2004}-$ staffing $_{j, 1998} \cdot{ }^{19}$ The definition of all the explanatory variables follows the same logic. Hence, the state-level regression is,

$$
\Delta \text { staffing }{ }_{j}=\beta_{0}+\beta_{1} \Delta I N C E N T_{j}+\beta_{2} \Delta G D P_{j}+\beta_{3} \Delta P O P_{j}+\beta_{4} \text { CITY }_{j}+\varepsilon_{j} .
$$

The change in tax enforcement incentives, $\triangle I N C E N T_{j}$, is measured alternatively as (a) change in tax-back rates, $\triangle T B R_{j}=T B R_{j, 2004}-T B R_{j, 1998}$ (specification S1.1); (b) change in average rate of internalized marginal revenues, $\Delta a v_{j}(I M R)=a v_{j, 2004}\left(I M R_{i_{j}}\right)-a v_{j, 1998}\left(I M R_{i_{j}}\right)$ (specification S1.2). Further control variables include the change in gross domestic product per capita, $\triangle G D P_{j}$, the change in population density per square kilometer, $\triangle P O P_{j}$, and a citystate dummy, CITY. All underlying values for the construction of the variable are provide in Table A2 in the Appendix.

The results of the two specifications are displayed in Table 4. In the first specification, the regression coefficient of $\triangle T B R$ carries the expected sign (a higher incentive for enforcing the tax law means that fewer taxpayers are audited per full time employee in a state's financial administration). However, the coefficient is insignificant. One possible explanation provides the optimality condition (8): tax enforcement depends on the tax back rate together with the distribution of individual marginal tax rates. Accordingly, tax-back rates are only an imprecise proxy for the incentive of a state to enforce the tax law. ${ }^{20}$ Specification S1.2 considers the interaction of tax back rates and individual marginal tax rates by averaging the $I M R \mathrm{~s}$ of all taxpayers in a state. Now the regression coefficient pertaining $\Delta a v(I M R)$ carries the expected negative sign and is significant at a 10 percent level.

In sum, the results of the state-level approach support our research hypothesis that higher internalized returns of taxation lead to higher tax enforcement activities at the state level. However, a state-level analysis misses the complexity of the condition (8): it is the distribution of $I M R$ s over all the taxpayers in a state and not an average statistic that determines tax enforcement activities. Not controlling for differences in the distributions of the tax-relevant characteristics of the tax units in regression analysis could simply lead to

\footnotetext{
${ }^{19}$ The results for three year differences support our findings from the six year differences regarding sign and magnitude of effects but are not significant at the 10 percent level.

${ }^{20}$ This would to some extent explain the results in Baretti et al. (2002) who fail to find a robust link between the marginal rate of loss and the level of tax enforcement.
} 
spurious correlations. Considering the distributions of tax-relevant characteristics at the micro level of tax units is thus crucial for estimating how fiscal equalization impacts tax enforcement activities of the states. ${ }^{21}$ This can be best achieved by conducting a micro level analysis at tax unit level.

\section{Table 4 about here}

\subsection{Micro-econometric analysis}

\subsubsection{Regression approach}

The micro-level regression analysis is conducted with OLS. The dependent variable is the natural logarithm of total deductions. Suppressing individual, period, and state-level subscripts, the OLS regression is,

$$
\begin{aligned}
\ln (\Delta)=\alpha_{0}+ & \boldsymbol{\beta}^{\prime} \text { Incentives }+\boldsymbol{\gamma}^{\prime} \text { Year }+\boldsymbol{\delta}^{\prime} \text { Char }+\boldsymbol{\theta}^{\prime} \text { Source } \\
& +\boldsymbol{\vartheta}^{\prime}(\text { Source } \cdot \text { Period })+\boldsymbol{\mu}^{\prime} \text { State }+\varepsilon
\end{aligned}
$$

The bald expressions denote vectors. Incentives includes a changing set of variables that mirror the tax enforcement incentives. Altogether four specifications are tested. In specification S2.1, Incentives comprises a single variable: the taxpayer-specific internalized marginal tax revenue, $I M R$. The specification thus complies with the optimality condition (8) from the theoretical model. According to the model, we should expect a negative regression coefficient: The higher the incentive to enforce the tax law, the lower should be the granted tax deductions. In specification S2.2, Incentives includes two variables: $I M R$ and the marginal tax rates of each taxpayer. This set up tests for the role of $I M R$ after controlling for individual marginal tax rates. In specifications S2.3, Incentives solely includes the state-specific TBRs (but not the tax payer specific marginal tax rates. In specification S2.4 Incentives comprises the two components of IMR as separate variables: state-specific TBRs and individual marginal tax rates. Specification 2.4 is thus the most flexible specification. Particularly, it even allows TBRs and individual marginal tax rates to have opposing effects on the level of granted tax deductions.

Of course, to isolate the effect of Incentives on granted tax deductions it is important to control for other potential determinants of granted tax deductions. To control for period effects, the vector Year includes two period dummies for years 2001 and 2004. Char

\footnotetext{
${ }^{21}$ Studies building on macro data, instead, proxy such and other issues with auxiliary variables like an inequality index (e. g. Goodspeed, 2002).
} 
comprises the characteristics of the tax unit: the number of tax-relevant children, age, marital status and church membership. Source is a vector of seven dummies, one for each income source. A dummy is one if the taxpayer has some positive income from the particular income source; else it is zero. To capture changes in the tax law, we interact the income source dummies with the two period dummies for 2001 and 2004. Finally, the vector State comprises fifteen state dummies (base category is Baden-Wuerttemberg). Results from the four OLS regressions are summarized in Table 5.

\section{Table 5 about here}

Table 5 provides a summary of the regressions. The covariates of interest are subsumed under Incentives. All four regression specification, convey the same consistent story: the higher the incentive to enforce the tax law, the lower is the level of granted tax deductions (controlled for all other aforementioned covariates). According to specification S2.1 the regression coefficient for $I M R$ equals -1.227. Assuming that average granted deduction amount to 6,000 Euro (see Table A1), the coefficient indicates that rising the internalized tax revenue (IMR) by 5 percentage point lowers granted tax deduction by 360 Euro. According to specification S2.2, this inverse relationship between $I M R$ and tax deductions is confirmed even after additionally controlling for individual marginal tax rates. Specifications S2.3 and S2.4 show that both components of the $I M R, T B R$ and marginal tax rates, matter for granted tax deductions, and for both components the inverse relationship is reconfirmed.

\subsubsection{Natural experiments}

As outlined above, there are two groups of states: one group where TBRs vary over time (Schleswig-Holstein, Bavaria, and Hamburg); another group where TBRs are about constant over time. Accordingly, tax-enforcement incentives (captured by $T B R$ ) change in the former but not in the latter group. Since $T B R$ is an exogenous variable from the viewpoint of the states, the setting is like a natural experiment: residents of the former states are the "treated," and residents of the latter are the "controls."

The econometric device to isolate the effect of the treatment is the difference-in-differences estimator (DiD). The DiD estimator is the difference between two differences: the difference in tax deductions before and after treatment among the treated, and the same difference among the controls. The control group should be composed of tax units resident in states with an inter-temporally stable $T B R$ with tax-relevant characteristics similar to the treated. 
Schleswig-Holstein experienced with a decrease of about 45 percentage points between 1998 and 2001 the most pronounced change of its $T B R$, and thus might be viewed as the ideal candidate for implementing the DiD approach. Two further potential candidates are Bavaria and Hamburg. Bavaria's 2001 TBR is about 4.2 percentage points lower than in 1998; Hamburg's TBR doubles between 2001 and 2004. The treatment in Schleswig-Holstein and Bavaria should lower the states' incentives because it lowered the share of a marginal tax Euro that can be internalized. Accordingly, the two states' DiD estimators should carry a positive sign. With the same logic, the DiD estimator for Hamburg should be negative.

For establishing experimental conditions it is important to find adequate control states (with $T B R$ varying little over time) and to identify tax units where the treatment or non-treatment is certain. To isolate the effect of the $T B R$ we restrict our control and treatment groups to tax units in the top income bracket $\left(y_{i}>60.000\right.$ respectitivley $y_{i}>120.000$ for joint filers). First, this enables us to look exclusively at the TBR for identifying the treated tax units (hence high income tax units face the identical marginal tax rate and the $I M R$ is the equal within in each state). Second, this ensures that the fundamental change in the income tax tariff between 1998 and 2004 does not artificially alter the distributions of marginal tax rates within each state and prohibits us from constructing the appropriate treatment and control samples. Still, the top income tax bracket is affected. Between 1998 and 2004, the top marginal tax rate was lowered from 53 to 45 percent. This, however, should be captured by a common time trend and poses no problem. Furthermore, the characteristics of the treated in the control group (residents of the control states) have to be reproduced. The standard procedure to achieve this goal is statistical matching. After the matching, the effect of the treatment on the treated is estimated over the common support, $S$, i.e. the part of the distribution of characteristics $X$ that is both represented among the treated and the controls. As our analysis relies on repeated cross-sections, we have implemented the statistical matching over three groups: the treated and the non-treated in the initial period before treatment, $t_{0}$, and the non-treated at $t_{1}$ (Blundell and Costa-Dias, 2008, p. 58). Then the difference-in-differences (DiD) estimator after matching is (Blundell and Costa-Dias, 2008, p. 59),

$$
\hat{\alpha}=\sum_{i \in T_{1}}\left\{\left[\Delta_{i t_{1}}-\sum_{k \in T_{0}} \widetilde{w}_{i k t_{0}}^{T} \Delta_{i t_{0}}\right]-\left[\sum_{k \in T_{0}} \widetilde{w}_{i k t_{1}}^{C} \Delta_{i t_{1}}-\sum_{k \in T_{0}} \widetilde{w}_{i k t_{0}}^{C} \Delta_{i t_{0}}\right]\right\} w_{i} .
$$

In equation (11), $\left(T_{0}, T_{1}\right)$ denote the treatment before and after treatment and $\left(C_{0}, C_{1}\right)$ the respective control groups; $\widetilde{w}_{i k t}^{C}$ denotes the weight attributed to tax unit $k$ belonging to group 
$G$ in period $t$ when comparing with the treated tax unit $i ; w_{i}$ reconstructs the outcome distribution for the treated in the base sample.

To implement the difference-in-differences estimator (11), propensity scores must be estimated using both the treated and the controls. In case of multiple cross-sections, the dependent variable, the dummy variable $d$ indicating the base sample after treatment, is set to one if the tax unit is treated and the observation period is $t_{1}\left(G=T_{1}\right)$ and to zero otherwise. Then the two control groups $\left(G=C_{0}, C_{1}\right)$ and the treated before treatment $\left(G=T_{0}\right)$ are matched to the treated after treatment separately. Accordingly, the common support $S$ comprises the treated units for whom a counterfactual tax unit is found in all three control samples (Blundell and Costa Dias, 2008).

The natural experiments underlying our DiD approach encompass Schleswig-Holstein 19982001, Bavaria 1998-2001, and Hamburg 2001-2004.

As outlined above, the DiD approach relies on four groups $T_{0}, T_{1}, C_{0}$ and $C_{1}$ :

1. Treated tax units in the period posterior to treatment, $t_{1}$, form the base samples, denoted $T_{1}$. We have three base samples: Tax units residing in Schleswig-Holstein in 2001, in Bavaria in 2001, and in Hamburg in 2004.

2. Each of the three base samples is statistically matched with three samples: (a) tax units resident in the treated state in the period ex ante to treatment, $t_{0}$, sample $T_{0}$; (b) tax units resident in the control states in period $t_{0}$, sample $C_{0}$; (c) tax units resident in the control states in period $t_{1}, C_{1}$.

The tax units forming the two samples $C_{0}$ and $C_{1}$ are residents of those states who exhibited vary little variation in $T B R$ between $t_{1}$ and $t_{0}{ }^{22}$

Ex ante to the statistical matching we have partitioned the treat and control samples in four sub-groups by marital and parental status (having children or not). Partitioning means that matches between observations in different sub-groups are not allowed. Partitioning by marital and parental status is important for the reliability of the DiD estimates, because tax burdens of the partitioned groups systematically differ due to splitting boon and child-related tax allowances.

For each partitioned group, we have implemented a prospensity score based nearest-neighbor matching: an observation from the potential control group is chosen as a matching partner for a treated observation that is closest in terms of the propensity score. The matching considers

\footnotetext{
${ }^{22}$ For Bavaria and Schleswig Holstein the control sample is drawn from tax units residing in non-city states. Hence, Lower Saxony, North Rhine-Westphalia, Hesse, Rhineland-Palatine, Baden-Württemberg, Saarland, Brandenburg, Mecklenburg-Western Pomerania, Saxony, Saxony-Anhalt and Thuringia serve as pool. For Hamburg, the control sample is drawn exclusively from tax units residing in the city states Berlin and Bremen.
} 
the following characteristics of the tax units: taxable base before discretionary deductions and its square; ${ }^{23}$ number of children (for the two sub-groups where children are present); age; dummies for the seven income sources (1 if revenues are positive; zero else); and church membership. ${ }^{24}$ Up to five neighbors had been allowed.

Figures A1a to A1c in the Appendix provide the resulting propensity score distributions. Results for Schleswig Holstein are provided in Figure A1a, for Bavaria in A1b, and for Hamburg in A1c. In each of the Figures, three symmetry plots are provided. Each symmetry plot depicts the propensity score distribution for the treated group after treatment, $T_{1}$ (black shaded distribution above the horizontal axis), against one of the three groups, $T_{0}, C_{0}$ or $C_{1}$ (distribution below the horizontal axis). As can be seen from the graphs, the propensity scores are highly symmetric, indicating that the distributions of observational characteristics are similar across groups. This can also be seen from the descriptive statistics provided in Tables A4a to A4c in the Appendix.

Difference-in-differences estimators from equation (11) together with jackknife standard errors are summarized in Table 6. Further, the effect of treatment on collected income taxes in a treated state is provided. To compute this effect, we, first, have applied the tax schedule of period $t_{1}$ to the taxable bases of the treated in $t_{1}$. This gives the original tax burdens of the treated. Subsequently, we have corrected for the treatment by adding $\hat{\alpha}$ to the taxable bases, and simulated the counterfactual treatment-corrected individual tax burdens by applying the respective tax tariff. Finally, we have computed differences between treatment-corrected and original tax burdens, and aggregated the differences over all the treated tax units. Consequently, a positive (negative) number translates into forgone (additional) tax revenue.

\section{Table 6 about here}

Results for Schleswig-Holstein are provided in the first panel of Table 6. Between 1998 and 2001, the TBR of Schleswig Holstein has dropped from 57.05 to 12.15 percent. Accordingly, the internalized marginal returns dropped substantially, lowering the incentives to enforce the income tax law (reflected by higher tax deductions). Indeed, the average treatment effect on the treated suggests that, as result, average tax deductions granted to a 'rich' taxpayer in

\footnotetext{
23 We have included the squared taxable base because the relationship between the taxable base and discretionary deductions is non-linear. With respect to the matching, inclusion of the squared taxable base requires balancing on both the first and second moments of the covariate distributions.

${ }^{24}$ Controlling for church membership is important because paying church taxes reduces the marginal income tax burden, and thus the marginal income-tax revenue.
} 
Schleswig-Holstein increased by about 2,564 Euros, resulting in forgone tax revenues of about 1,194 Euros per unit and 31 million in total.

Results for Bavaria are provided in the second panel of Table 6. Between 1998 and 2001, the $T B R$ of Bavaria has dropped from 26.59 to 22.34 percent. Accordingly, we should again expect a positive average treatment effect. The result is consistent with expectations: the drop of $T B R$ increases the level of granted tax deductions. However, compared to Schleswig Holstein the effect is smaller in absolute terms, most likely because Schleswig Holstein's $T B R$ decreased much stronger. Forgone tax revenue amounts to about 576 Euro per rich resident of Bavaria, and to about 98 million in total.

Results for Hamburg are provided in the third panel of Table 6. In contrast to Schleswig Holstein and Bavaria, Hamburg's TBR has increased over time: from 8.5 percent in 2001 to 17.08 percent in 2004. So, now we should expect a negative average treatment effect; and again the expectation is confirmed by the estimator. The increase of Hamburg's TBR means that the incentives to enforce the tax law have increased. As a result, granted tax deductions are lower, resulting in higher tax revenue per tax payer and 11 million rise in tax revenue.

\section{Conclusion}

In many federations, fiscal-equalization schemes have been installed to soften fiscal imbalances across the member states. Various theoretical works have investigated the incentives of such cooperative systems. However, so far only a few studies addressed the research question of the present paper: whether fiscal equalization matters for the enforcement of a uniform tax by state governments.

By means of a stylized model we show that state authorities have incentives to align the effective tax rates of their residents to the internalized marginal returns from taxation. We empirically test the model using two workhorses, regressions and a natural-experiment design, and our estimates support the model's prediction: the higher the fraction of additional tax revenues a state internalizes, the stricter it enforces the tax law, as reflected in lower levels of tax deductions.

From the viewpoint of a single state it is rational to align tax enforcement activities with the fraction of additional tax revenue that the state internalizes. However, the alignment causes fiscal externalities, and these imply that state-specific tax enforcement activities are inefficient (too low) from the viewpoint of the overall economy. Further, differences in enforcement activity across the states violate the principle of equal treatment of equal, undermining the tax moral of the taxpayers. 
In principle, such problems can be rectified by shifting the tax enforcement responsibility to a central tax collection agency. Indeed, several initiatives have been set up in this direction in the last years in Germany. For example, in year 2007 a commission of German experts on federalism ("Föderalismuskommission II") discussed the installation of a central tax collecting agency. In the end, such initiatives have always been dismissed, failing against the resistence of German states.

\section{References}

Akai, N., and E. Silva (2009): Interregional Distribution as a Cure to the Soft Budget Syndrome in Federations, International Tax and Public Finance, 16, 43-58.

Audit Office of Berlin (Rechnungshof von Berlin) (2001): Jahresbericht 2001 des Rechnungshofs von Berlin gemäß Artikel 95 der Verfassung von Berlin und § 97 der Landeshaushaltsordnung, Berlin.

Baretti, C., Huber, B., and K. Lichtblau (2002): A Tax on Tax Revenue. The Incentive Effects of Equalizing Transfers: Evidence from Germany, International Tax and Public Finance, 9, 631-649.

Blundell, Richard W. and Costa Dias, Monica (2008): Alternative Approaches to Evaluation in Empirical Microeconomics, IZA Discussion Paper No. 3800.

Boadway, R., and F.R. Flatters (1982): Efficiency and Equalization Payments in a Federal System of Government: A Synthesis and Extension of Recent Results, Canadian Journal of Economics, 15, 613-633.

Boadway, R., Horiba, I., and R. Jha (1995): The Design of Conditional Grants as a PrincipalAgent Problem, Manuscript, Queen’s University.

Bönke, T., B. Jochimsen and C. Schröder (2011): Fiscal equalization and regions' (un)willingness-to-tax - evidence from Germany, Economics Working Paper, Department of Economics, Christian-Albrechts-Universität Kiel, Nr. 2011/6.

Bordignon, M., Manasse, P., and G. Tabellini (2001): Optimal Regional Redistribution Under Asymmetric Information, American Economic Review, 91, 709-723.

Breuillé, M.-L., and R. Gary-Bobo (2007): Sharing Budgetary Austerity under Free Mobility and Asymmetric Information: An Optimal Regulation Approach to Fiscal Federalism, Journal of Public Economics, 91, 1177-1196.

Bucovetsky, S., Marchand, M., and P. Pestieau (1998): Tax Competition and Revelation of Preferences for Public Expenditure, Journal of Urban Economics, 44, 367-390.

Buettner, T. (2006): The Incentive Effect of Fiscal Equalization Transfers on Tax Policy, Journal of Public Economics, 90, 477-497.

Caplan, A.J., Cornes, R.C. and E.C.D. Silva (2000): Pure Public Goods and Income Redistribution in a Federation with Decentralized Leadership and Imperfect Labor Mobility, Journal of Public Economics, 77, 265-284.

Cremer, H., Marchand, M., and P. Pestieau (1996): Interregional Redistribution through Tax Surcharge, International Tax and Public Finance, 3, 157-173. 
Edwards, J., and M. Keen (1996): Tax Competition and Leviathan, European Economic Review, 40, 113-134.

Egger, P., Koethenbuerger, M., and M. Smart (2009): Do Fiscal Transfers Alleviate Business Tax Competition? Evidence from Germany, Journal of Public Economics, 94, 197336.

Esteller-Moré, A. (2005): Is there a Connection Between the Tax Administration and the Political Power?, International Tax and Public Finance, 12, 639-663.

Goodspeed, T.J. (2002): Tax Competition and Tax Structure in Open Federal Economies: Evidence from OECD Countries with Implications for the European Union, European Economic Review, 46, 357-374.

Federal Audit Office (Bundesrechnungshof) (2012): Bericht nach §99 BHO über den Vollzug der Steuergesetze, insbesondere im Arbeitnehmerbereich, Bonn.

Federal Audit Office (Bundesrechnungshof) (2009): Bemerkungen 2009 zur Haushalts- und Wirtschaftsführung des Bundes, Bonn.

Federal Audit Office (Bundesrechnungshof) (2006): Probleme beim Vollzug der Steuergesetze, Schriftenreihe des Bundesbeauftragten für Wirtschaftlichkeit in der Verwaltung, Stuttgart: Kohlhammer.

Federal Ministry of Finance (Bundesministerium der Finanzen) (2012): Kassenmäßige Steuereinnahmen nach Steuerarten in den Kalenderjahren 2010-2011, http://www.bundesfinanzministerium.de/Content/DE/Standardartikel/Themen/Steuern/ Steuerschaetzungen_und_Steuereinnahmen/2012-05-29-steuereinnahmen-nachsteuerarten-2010-2011.pdf?_blob=publicationFile\& (November 21, 2012).

Inman, R.P., and D.L. Rubinfeld (1992): Fiscal Federalism in Europe - Lessons from the United States Experience, European Economic Review, 36, 654-660.

Jochimsen, B., and R. Nuscheler (2011), The Political Economy of the German Länder Deficits: Weak Governments Meet Strong Finance Ministers, Applied Economics, 43, 2399-2416.

Libman, A., and L.P. Feld (2007): Strategic Tax Collection and Fiscal Decentralisation: The Case of Russia, CESifo Working Paper, 2031.

Liebig, T., Puhani, P., and A. Sousa-Poza (2007): Taxation and Internal Migration - Evidence from the Swiss Census using Community-Level Variation in Income Tax Rates, Journal of Regional Science, 47(4), 807-836.

Manasse, P, and C. Schultz (1999): Regional Redistribution and Migration, IGIER Working Paper, 146.

Martinez-Vazquez, J., and A. Timofeev (2005): Choosing between Centralized and Decentralized Models of Tax Administration, ISP Working Paper, 05-02, Georgia State University.

Mikesell, J.L. (2003): International Experiences with Administration of Local Taxes: A Review of Practices and Issues, Tax Policy and Administration Thematic Group, The World Bank.

Musgrave, R.M. (1959): The Theory of Public Finance, New York: McGraw-Hill.

Oates, W.E. (1999): An Essay on Fiscal Federalism, Journal of Economic Literature, 37, 1120-1149.

Oates, W.E. (1972): Fiscal Federalism, New York: Harcourt Brace Jovanovich. 
Plachta, R. (2008): Schuldenfalle Finanzausgleich - Theoretische und empirische Analyse der deutschen Finanzverfassung, Köln.

Raff, H., and J.D. Wilson (1997): Income Redistribution with Well-Informed Local Governments, International Tax and Public Finance, 4, 407-427.

Samuelson, P.A. (1954): The Pure Theory of Public Expenditure, Review of Economics and Statistics, 36, 387-389.

Schick, G. (2011): Schwarz-gelbe Landesregierungen betreiben laxen Steuervollzug - und nehmen Ungerechtigkeiten und höhere Schulden in Kauf, http://www.gerhardschick.net/images/stories/Steuerpolitik/argumentationspapier\%20st euervollzug.pdf (March 11, 2011).

Traxler, T. and A. Reutter (2008): Apportionment, Fiscal Equalization and Decentralized Tax Enforcement, Working Paper Series of the Max Planck Institute for Research on Collective Goods 2008_21, Max Planck Institute for Research on Collective Goods.

Vogel, H. (2000): Ungleichheiten beim Vollzug von Steuergesetzen im Bundesstaat Juristische und ökonomische Aspekte, Peter Lang Verlag: Frankfurt et al. 
Table 1. Germany’s fiscal equalization system

Stage 1

Stage 2

Stage 3

Stage 4

\begin{tabular}{|c|c|c|c|c|}
\hline Type & Revenue sharing & $\begin{array}{c}\text { VAT } \\
\text { distribution }\end{array}$ & $\begin{array}{l}\text { Horizontal equalization } \\
\text { payments }\end{array}$ & $\begin{array}{l}\text { Supplementary } \\
\text { federal grants }\end{array}$ \\
\hline Instrument & $\begin{array}{l}\text { Revenue sharing of } \\
\text { joint taxes (income, } \\
\text { corporation, VAT) } \\
\text { according to fixed } \\
\text { division rules }\end{array}$ & $\begin{array}{l}\text { Distribution of } \\
\text { VAT revenue } \\
\text { amongst the } \\
\text { states }\end{array}$ & $\begin{array}{l}\text { Transfers from } \\
\text { financially strong states } \\
\text { (above average joint- } \\
\text { tax-revenues) to } \\
\text { financially weak ones } \\
\text { (below average) }\end{array}$ & $\begin{array}{l}\text { Transfers from the } \\
\text { federal government } \\
\text { to states whose } \\
\text { fiscal revenue is } \\
\text { still below average }\end{array}$ \\
\hline $\begin{array}{l}\text { Fiscal } \\
\text { effect }\end{array}$ & $\begin{array}{l}\text { Fixed rate of loss for } \\
\text { provinces, e.g. } 42.5 \% \\
\text { for income tax re- } \\
\text { venue, i.e. they keep } \\
57.5 \% \text { of income tax } \\
\text { revenue. }\end{array}$ & $\begin{array}{l}\text { All states } \\
\text { receive at least } \\
\text { 92\% of average } \\
\text { (per capita) tax } \\
\text { revenue }\end{array}$ & $\begin{array}{l}\text { All states receive at } \\
\text { least } 95 \% \text { of average } \\
\text { (per capita) fiscal } \\
\text { revenue }\end{array}$ & $\begin{array}{l}\text { All states receive at } \\
\text { least } 99.5 \% \text { of } \\
\text { average (per capita) } \\
\text { fiscal revenue }\end{array}$ \\
\hline
\end{tabular}

Note. In addition to stage 1 to 4 some provinces receive special need grants that are paid lump-sum.

Table 2. Tax back rates

\begin{tabular}{lcccc} 
& & \multicolumn{3}{c}{ TBR (in \%) } \\
State & Acronym & $\mathbf{1 9 9 8}$ & $\mathbf{2 0 0 1}$ & $\mathbf{2 0 0 4}$ \\
\hline Schleswig-Holstein & SH & 57.05 & 12.15 & 12.16 \\
Hamburg & HH & 8.80 & 8.50 & 17.08 \\
Lower Saxony & NI & 14.97 & 12.19 & 12.83 \\
Bremen & HB & 8.39 & 8.38 & 8.38 \\
North Rhine-Westphalia & NW & 29.07 & 29.63 & 29.46 \\
Hesse & HE & 19.20 & 20.08 & 19.41 \\
Rhineland-Palatine & RP & 12.84 & 12.83 & 12.84 \\
Baden-Württemberg & BW & 21.12 & 21.98 & 22.45 \\
Bavaria & BV & 26.59 & 22.34 & 23.37 \\
Saarland & SL & 8.14 & 8.13 & 8.12 \\
Berlin & BE & 10.19 & 10.16 & 10.16 \\
Brandenburg & BB & 9.02 & 9.03 & 9.01 \\
Mecklenburg-Western Pomerania & MV & 8.56 & 8.54 & 8.51 \\
Saxony & SN & 10.17 & 10.1 & 10.04 \\
Saxony-Anhalt & ST & 9.09 & 9.03 & 8.97 \\
Thuringia & TH & 8.96 & 8.92 & 8.89 \\
\hline No. OwW & & & & \\
\hline
\end{tabular}

Note. Own calculations. 
Table 3. Average state level internalized marginal tax revenues

\begin{tabular}{lcccc} 
& & \multicolumn{3}{c}{$\operatorname{av}(I M R)$ (in \%): } \\
State & Acronym & $\mathbf{1 9 9 8}$ & $\mathbf{2 0 0 1}$ & $\mathbf{2 0 0 4}$ \\
\hline Baden-Württemberg & BW & 6.66 & 6.18 & 6.09 \\
Bavaria & BV & 8.21 & 6.16 & 6.19 \\
Berlin & BE & 3.13 & 2.74 & 2.54 \\
Brandenburg & BB & 2.44 & 2.12 & 2.06 \\
Bremen & HB & 2.57 & 2.25 & 2.13 \\
Hamburg & HH & 2.81 & 2.40 & 4.57 \\
Hesse & HE & 6.03 & 5.63 & 5.20 \\
Mecklenburg-Western Pomerania & MV & 2.24 & 1.92 & 1.85 \\
Lower Saxony & NI & 4.49 & 3.26 & 3.33 \\
North Rhine-Westphalia & NW & 9.03 & 8.17 & 7.81 \\
Rhineland-Palatine & RP & 3.93 & 3.49 & 3.37 \\
Saarland & SL & 2.46 & 2.20 & 2.12 \\
Saxony & SN & 2.66 & 2.26 & 2.17 \\
Saxony-Anhalt & ST & 2.35 & 2.01 & 1.95 \\
Schleswig-Holstein & SH & 17.65 & 3.32 & 3.18 \\
Thuringia & TH & 2.32 & 2.00 & 1.95 \\
\hline
\end{tabular}

Note. The average marginal tax revenue is calculated as the state specific average marginal tax rate multiplied with one minus the state's tax back rate. Average marginal tax rates are provided in Table A1. Own calculations.

Table 4. State level regression

Specification S1.1 S1.2

\begin{tabular}{|c|c|c|c|c|}
\hline \multicolumn{5}{|c|}{ Dependent variable: $\Delta$ staffing } \\
\hline$\triangle T B R$ & -71.323 & $(42.290)$ & & \\
\hline$\Delta a v(I M R)$ & & & $-244.987 *$ & $(136.323)$ \\
\hline$\triangle G D P$ & $0.012 * *$ & $(0.004)$ & $0.012 * *$ & $(0.004)$ \\
\hline$\triangle P o p$ & 0.071 & $(0.324)$ & 0.047 & $(0.320)$ \\
\hline City & $33.265 * *$ & (11.857) & $33.975 * *$ & $(11.766)$ \\
\hline Constant & $46.673 * * *$ & $(7.142)$ & $44.614 * * *$ & $(7.571)$ \\
\hline $\mathrm{R}^{2}$ & 0.382 & & 0.399 & \\
\hline F statistic & 3.318 & & 3.487 & \\
\hline Observations & 16 & & 16 & \\
\hline \multicolumn{5}{|c|}{$\begin{array}{l}\text { Note. Ordinary least squares regression, standard errors in parentheses. Levels of significance: } * 10 \%, * * 5 \%, * * * 1 \% \text {. All } \\
\text { variables denoted with } \Delta \text { are calculated as difference between } 1998 \text { and } 2004 \text {. Underlying values for the variables are provided } \\
\text { in Table } 2(\triangle T B R) \text {, Table } 3(\Delta a v(I M R)) \text { and Table A2 ( } \Delta \text { staffing: difference in relative staffing; } \Delta G D P: \text { difference in per } \\
\text { capita GDP; } \triangle P o p \text { : difference in population density) in the Appendix. Data. Federal Statistical Office, Income Tax Statistics, } \\
\text { Own Calculation. }\end{array}$} \\
\hline
\end{tabular}


Table 5. Regression results

Specification

S2.1

S2.2

S2.3

S2.4

\begin{tabular}{|c|c|c|c|c|c|c|c|c|}
\hline \multicolumn{9}{|l|}{ Dependent variable: $\ln \left(\Delta_{i}\right)$} \\
\hline \multicolumn{9}{|l|}{ Incentives } \\
\hline$I M R$ & $-1.227 * * *$ & $(0.015)$ & $-0.167 * * *$ & $(0.017)$ & & & & \\
\hline$T B R$ & & & & & $-0.036 * * *$ & $(0.007)$ & $-0.033^{* * *}$ & $(0.007)$ \\
\hline$\partial t_{i} / \partial \Delta_{i}$ & & & $-0.798 * * *$ & $(0.006)$ & & & $-0.827 * * *$ & $(0.006)$ \\
\hline \multicolumn{9}{|l|}{ Year } \\
\hline year $_{2001}$ & $-0.100 * * *$ & $(0.003)$ & $-0.113^{* * *}$ & $(0.003)$ & $-0.089 * * *$ & $(0.003)$ & $-0.113^{* * *}$ & $(0.003)$ \\
\hline year $_{2004}$ & $-0.293 * * *$ & $(0.003)$ & $-0.312 * * *$ & $(0.003)$ & $-0.283 * * *$ & $(0.003)$ & $-0.312^{* * *}$ & $(0.003)$ \\
\hline \multicolumn{9}{|l|}{ Char } \\
\hline $\ln \left(y_{i}\right)$ & $0.624 * * *$ & $(0.001)$ & $0.709 * * *$ & $(0.001)$ & $0.593 * * *$ & $(0.000)$ & $0.709 * * *$ & $(0.001)$ \\
\hline children & $0.255^{* * *}$ & $(0.000)$ & $0.256 * * *$ & $(0.000)$ & $0.256 * * *$ & $(0.000)$ & $0.256 * * *$ & $(0.000)$ \\
\hline age & $0.103^{* * *}$ & $(0.000)$ & $0.103^{* * *}$ & $(0.000)$ & $0.103^{* * *}$ & $(0.000)$ & $0.103^{* * *}$ & $(0.000)$ \\
\hline married & $0.131^{* * *}$ & $(0.001)$ & $0.074 * * *$ & $(0.001)$ & $0.073 * * *$ & $(0.001)$ & $0.073^{* * *}$ & $(0.001)$ \\
\hline church & $0.138 * * *$ & $(0.001)$ & $0.140 * * *$ & $(0.001)$ & $0.139 * * *$ & $(0.001)$ & $0.139 * * *$ & $(0.001)$ \\
\hline \multicolumn{9}{|l|}{ Source } \\
\hline agriculture/ forestry & $0.549 * * *$ & $(0.003)$ & $0.544 * * *$ & $(0.003)$ & $0.547 * * *$ & $(0.003)$ & $0.544 * * *$ & $(0.003)$ \\
\hline business & $0.181^{* * *}$ & $(0.002)$ & $0.184^{* * *}$ & $(0.002)$ & $0.178 * * *$ & $(0.002)$ & $0.183^{* * *}$ & $(0.002)$ \\
\hline self employment & $0.250 * * *$ & $(0.002)$ & $0.256 * * *$ & $(0.002)$ & $0.245^{* * *}$ & $(0.002)$ & $0.256 * * *$ & $(0.002)$ \\
\hline employment & $0.134 * * *$ & $(0.002)$ & $0.139 * * *$ & $(0.002)$ & $0.131^{* * *}$ & $(0.002)$ & $0.139 * * *$ & $(0.002)$ \\
\hline investment & $0.161^{* * *}$ & $(0.002)$ & $0.165^{* * *}$ & $(0.002)$ & $0.155^{* * *}$ & $(0.002)$ & $0.165^{* * *}$ & $(0.002)$ \\
\hline rent/lease & $0.089 * * *$ & $(0.002)$ & $0.091 * * *$ & $(0.002)$ & $0.085^{* * *}$ & $(0.002)$ & $0.090 * * *$ & $(0.002)$ \\
\hline other & $0.208 * * *$ & $(0.002)$ & $0.198 * * *$ & $(0.002)$ & $0.214 * * *$ & $(0.002)$ & $0.198 * * *$ & $(0.002)$ \\
\hline \multicolumn{9}{|l|}{ Source $\cdot$ year 2001} \\
\hline agriculture/ forestry & $-0.061 * * *$ & $(0.004)$ & $-0.055^{* * *}$ & $(0.004)$ & $-0.051 * * *$ & $(0.004)$ & $-0.054 * * *$ & $(0.004)$ \\
\hline business & $0.016^{* * *}$ & $(0.002)$ & $0.013^{* * *}$ & $(0.002)$ & $0.020 * * *$ & $(0.002)$ & $0.013 * * *$ & $(0.002)$ \\
\hline self employment & $-0.020 * * *$ & $(0.003)$ & $-0.022 * * *$ & $(0.003)$ & $-0.014 * * *$ & $(0.003)$ & $-0.022 * * *$ & $(0.003)$ \\
\hline employment & $-0.072 * * *$ & $(0.002)$ & $-0.076 * * *$ & $(0.002)$ & $-0.067 * * *$ & $(0.002)$ & $-0.075^{* * *}$ & $(0.002)$ \\
\hline investment & $-0.089 * * *$ & $(0.002)$ & $-0.089 * * *$ & $(0.002)$ & $-0.084 * * *$ & $(0.002)$ & $-0.089 * * *$ & $(0.002)$ \\
\hline rent/lease & $-0.021 * * *$ & $(0.002)$ & $-0.018 * * *$ & $(0.002)$ & $-0.017 * * *$ & $(0.002)$ & $-0.018 * * *$ & $(0.002)$ \\
\hline other & $0.077 * * *$ & $(0.002)$ & $0.074 * * *$ & $(0.002)$ & $0.075^{* * *}$ & $(0.002)$ & $0.074 * * *$ & $(0.002)$ \\
\hline \multicolumn{9}{|l|}{ Source $\cdot$ year $_{2004}$} \\
\hline agriculture/ forestry & 0.005 & $(0.004)$ & $0.010^{* *}$ & $(0.004)$ & $0.015^{* * *}$ & $(0.004)$ & $0.011^{* *}$ & $(0.004)$ \\
\hline business & $-0.041 * * *$ & $(0.002)$ & $-0.047 * * *$ & $(0.002)$ & $-0.036 * * *$ & $(0.003)$ & $-0.046 * * *$ & $(0.002)$ \\
\hline self employment & $0.006^{* *}$ & $(0.003)$ & -0.002 & $(0.003)$ & $0.013^{* * *}$ & $(0.003)$ & -0.001 & $(0.003)$ \\
\hline employment & $0.043^{* * *}$ & $(0.003)$ & $0.036^{* * *}$ & $(0.003)$ & $0.048 * * *$ & $(0.003)$ & $0.037 * * *$ & $(0.003)$ \\
\hline investment & $-0.049 * * *$ & $(0.003)$ & $-0.053 * * *$ & $(0.003)$ & $-0.042 * * *$ & $(0.003)$ & $-0.052 * * *$ & $(0.003)$ \\
\hline rent/lease & $0.037 * * *$ & $(0.002)$ & $0.038 * * *$ & $(0.002)$ & $0.041^{* * *}$ & $(0.002)$ & $0.039 * * *$ & $(0.002)$ \\
\hline other & $0.170 * * *$ & $(0.002)$ & $0.167 * * *$ & $(0.002)$ & $0.169 * * *$ & $(0.002)$ & $0.167 * * *$ & $(0.002)$ \\
\hline \multicolumn{9}{|l|}{ State } \\
\hline SH & $-0.024 * * *$ & $(0.002)$ & $-0.047 * * *$ & $(0.002)$ & $-0.047 * * *$ & $(0.002)$ & $-0.049 * * *$ & $(0.002)$ \\
\hline$H H$ & $-0.127 * * *$ & $(0.002)$ & $-0.095 * * *$ & $(0.002)$ & $-0.092 * * *$ & (0.002) & $-0.093 * * *$ & $(0.002)$ \\
\hline$N I$ & $-0.123 * * *$ & $(0.002)$ & $-0.100 * * *$ & $(0.002)$ & $-0.095 * * *$ & $(0.002)$ & $-0.098 * * *$ & $(0.002)$ \\
\hline$H B$ & $-0.138 * * *$ & $(0.003)$ & $-0.103^{* * *}$ & $(0.003)$ & $-0.100 * * *$ & $(0.003)$ & $-0.102 * * *$ & $(0.003)$ \\
\hline$N W$ & $-0.069 * * *$ & $(0.001)$ & $-0.094 * * *$ & (0.001) & $-0.095 * * *$ & $(0.001)$ & $-0.096 * * *$ & $(0.001)$ \\
\hline$H E$ & $-0.064 * * *$ & $(0.002)$ & $-0.057 * * *$ & $(0.002)$ & $-0.056 * * *$ & $(0.002)$ & $-0.057 * * *$ & $(0.002)$ \\
\hline$R P$ & $-0.075 * * *$ & $(0.002)$ & $-0.050 * * *$ & $(0.002)$ & $-0.047 * * *$ & $(0.002)$ & $-0.048 * * *$ & $(0.002)$ \\
\hline$B Y$ & $0.023 * * *$ & $(0.001)$ & $0.014^{* * *}$ & $(0.001)$ & $0.015^{* * *}$ & $(0.001)$ & $0.014 * * *$ & $(0.001)$ \\
\hline$S L$ & $-0.100 * * *$ & $(0.002)$ & $-0.066 * * *$ & $(0.003)$ & $-0.061 * * *$ & $(0.003)$ & $-0.064 * * *$ & (0.003) \\
\hline$B E$ & $-0.150 * * *$ & $(0.002)$ & $-0.120 * * *$ & $(0.002)$ & $-0.116 * * *$ & (0.002) & $-0.118 * * *$ & $(0.002)$ \\
\hline$B B$ & $-0.061 * * *$ & $(0.002)$ & $-0.033^{* * *}$ & $(0.002)$ & $-0.027 * * *$ & $(0.002)$ & $-0.032 * * *$ & $(0.002)$ \\
\hline$M V$ & $-0.034 * * *$ & $(0.002)$ & $-0.005^{* *}$ & $(0.002)$ & 0.001 & $(0.002)$ & $-0.005^{* *}$ & $(0.002)$ \\
\hline$S N$ & $0.012^{* * *}$ & $(0.002)$ & $0.038 * * *$ & $(0.002)$ & $0.044 * * *$ & $(0.002)$ & $0.038 * * *$ & $(0.002)$ \\
\hline$S T$ & $-0.056 * * *$ & $(0.002)$ & $-0.029 * * *$ & $(0.002)$ & $-0.023 * * *$ & $(0.002)$ & $-0.029 * * *$ & $(0.002)$ \\
\hline TH & $0.023 * * *$ & $(0.002)$ & $0.050 * * *$ & $(0.002)$ & $0.057 * * *$ & $(0.002)$ & $0.051 * * *$ & $(0.002)$ \\
\hline Constant & $1.324 * * *$ & $(0.005)$ & $0.670 * * *$ & $(0.007)$ & $1.555 * * *$ & $(0.005)$ & $0.643 * * *$ & $(0.009)$ \\
\hline $\mathrm{R}^{2}$ & 0.559 & & 0.561 & & 0.559 & & 0.561 & \\
\hline F statistic & $186,735.8$ & & $185,765.7$ & & $185,068.3$ & & $185,713.8$ & \\
\hline Observations & $5,990,667$ & & $5,990,667$ & & $5,990,667$ & & $5,990,667$ & \\
\hline
\end{tabular}

Note. Robust standard errors in parentheses. Levels of significance: * 10\%, ** 5\%, *** 1\%. Data. FAST $1998-2004$. 
Table 6. Treatment effects pertaining to tax units in the top income bracket

\begin{tabular}{|c|c|c|c|c|c|}
\hline State & $\begin{array}{c}\Delta T B R_{j}= \\
T B R_{j, t_{1}}-T B R_{j, t_{0}}\end{array}$ & $\begin{array}{c}\text { Average treatment } \\
\text { effect on the treated } \\
\text { (change in granted } \\
\text { deductions) }\end{array}$ & $\begin{array}{l}\text { Average change of } \\
\text { tax revenue }\end{array}$ & Number of tax units & $\begin{array}{l}\text { Change in total tax } \\
\text { revenue (in } \\
\text { millions) }\end{array}$ \\
\hline Schleswig-Holstein & -44.9 & $\begin{array}{l}2,563.598 \\
(256.148)\end{array}$ & $\begin{array}{c}-1,193.885 \\
(1.003)\end{array}$ & 25,899 & -30.914 \\
\hline Bavaria & -4.25 & $\begin{array}{c}1,237.469 \\
(89.555)\end{array}$ & $\begin{array}{l}-575.574 \\
(0.1888)\end{array}$ & 170,637 & -98.204 \\
\hline Hamburg & 8,58 & $\begin{array}{l}-929.669 \\
(204.897)\end{array}$ & $\begin{array}{c}305.669 \\
(0.957)\end{array}$ & 36,250 & 11.080 \\
\hline
\end{tabular}

Note. All results significant at the $1 \%$ level. Jackknife standard errors in parentheses. Number of tax units denotes "rich" tax units with gross taxable income in the top income bracket only.

Data. FAST 1998-2004. 
Figure 1a. Tax back rate and income tax revenue, 1998
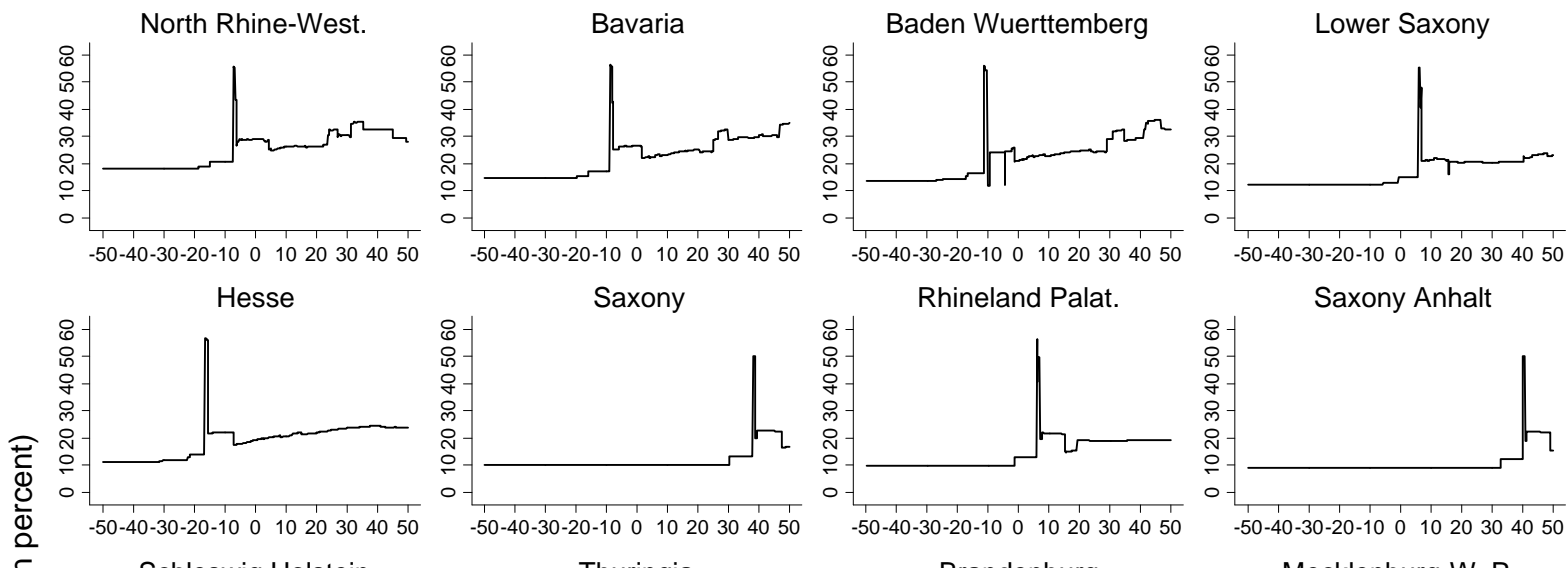

Saxony Anhalt
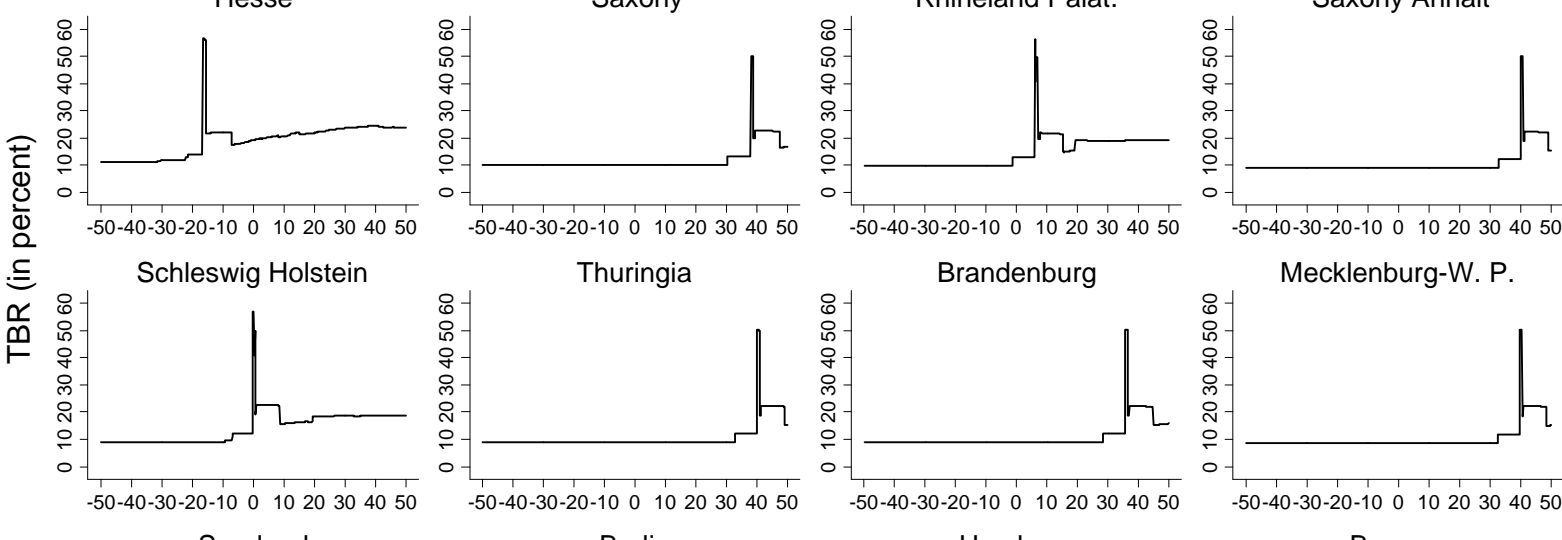

Mecklenburg-W. P.
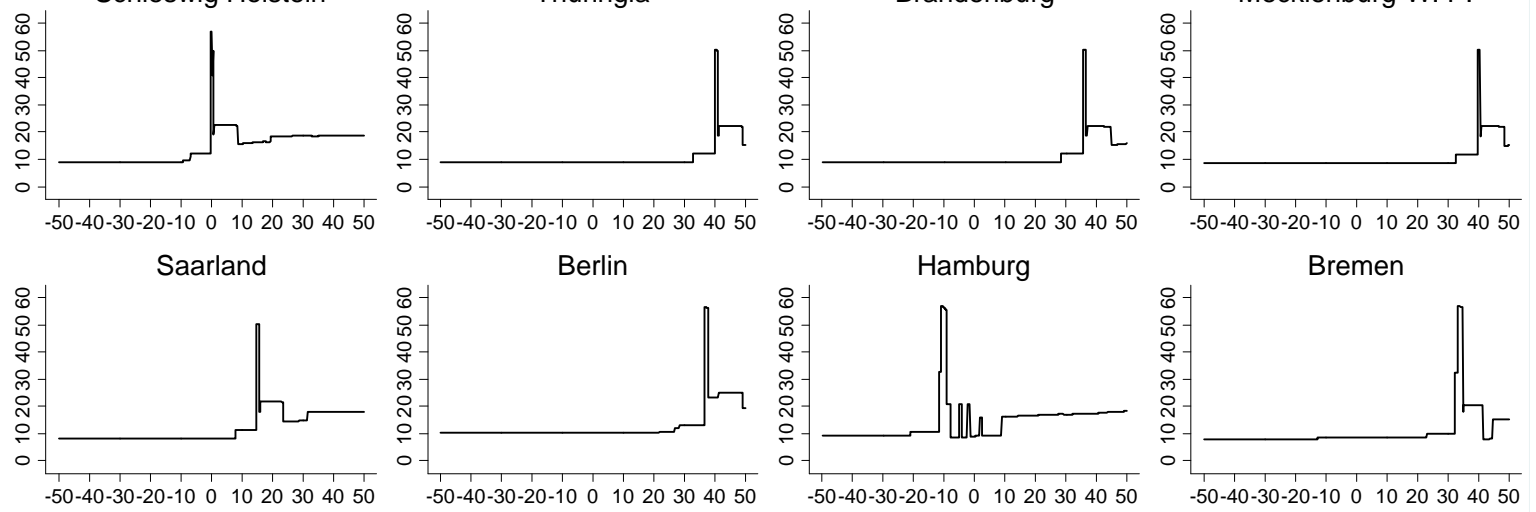
variation of income tax revenue per capita (in Euro)

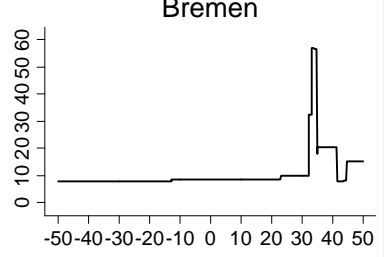

Note. Own computations. 
Figure 1b. Tax back rate and income tax revenue, 2001
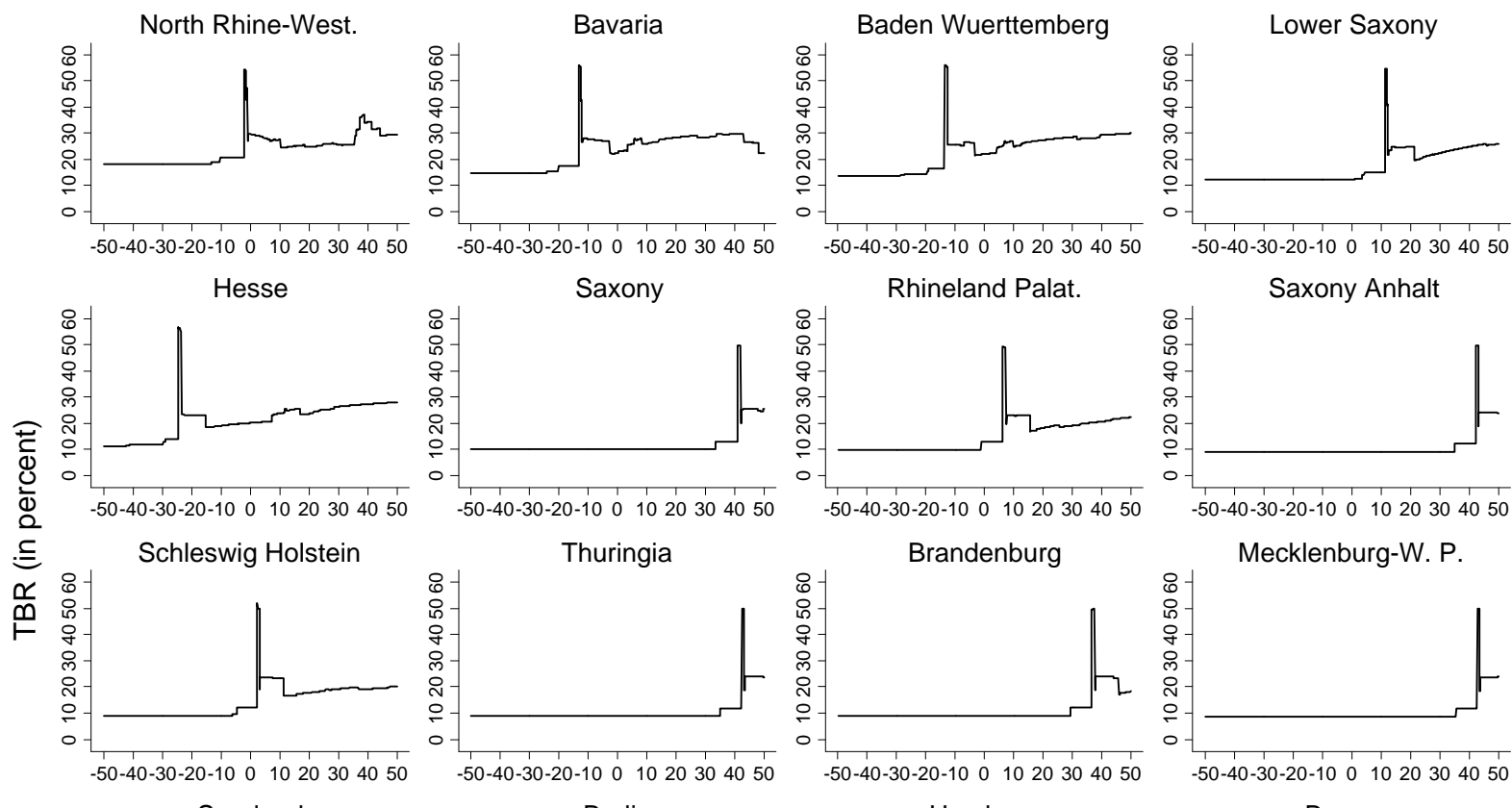

Mecklenburg-W. P.
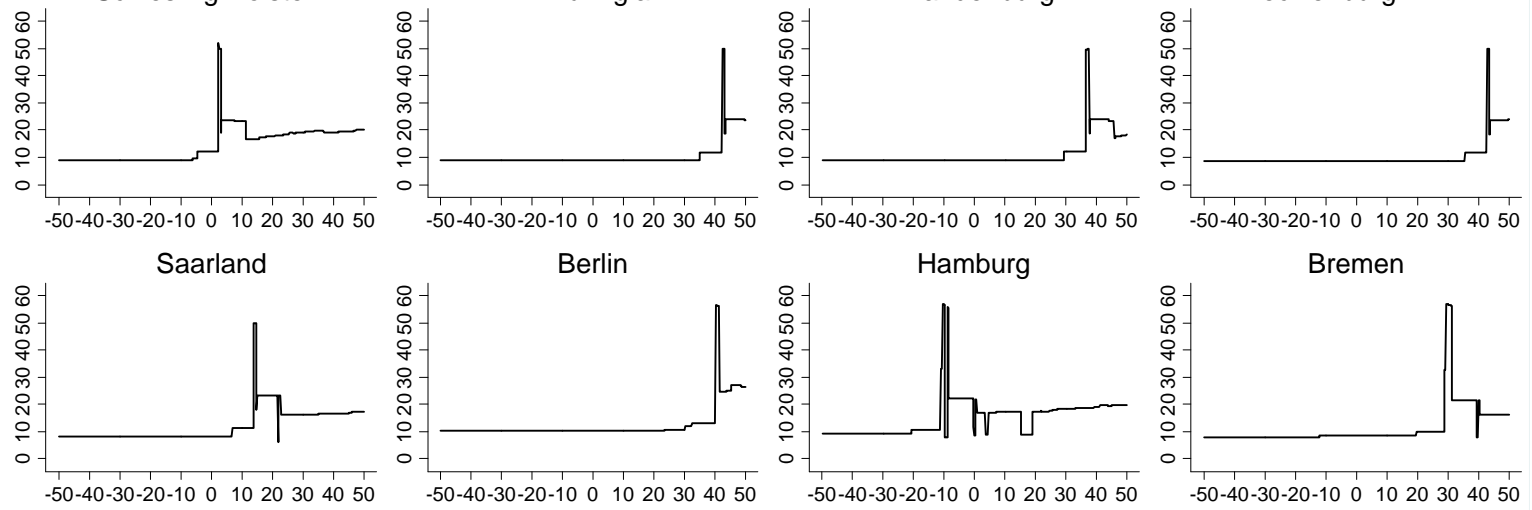
variation of income tax revenue per capita (in Euro)

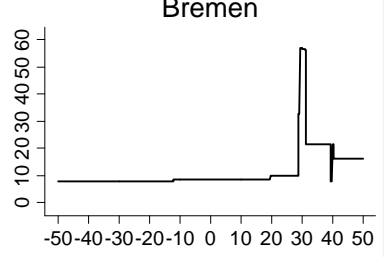

Note. Own computations. 
Figure 1c. Tax back rate and income tax revenue, 2004
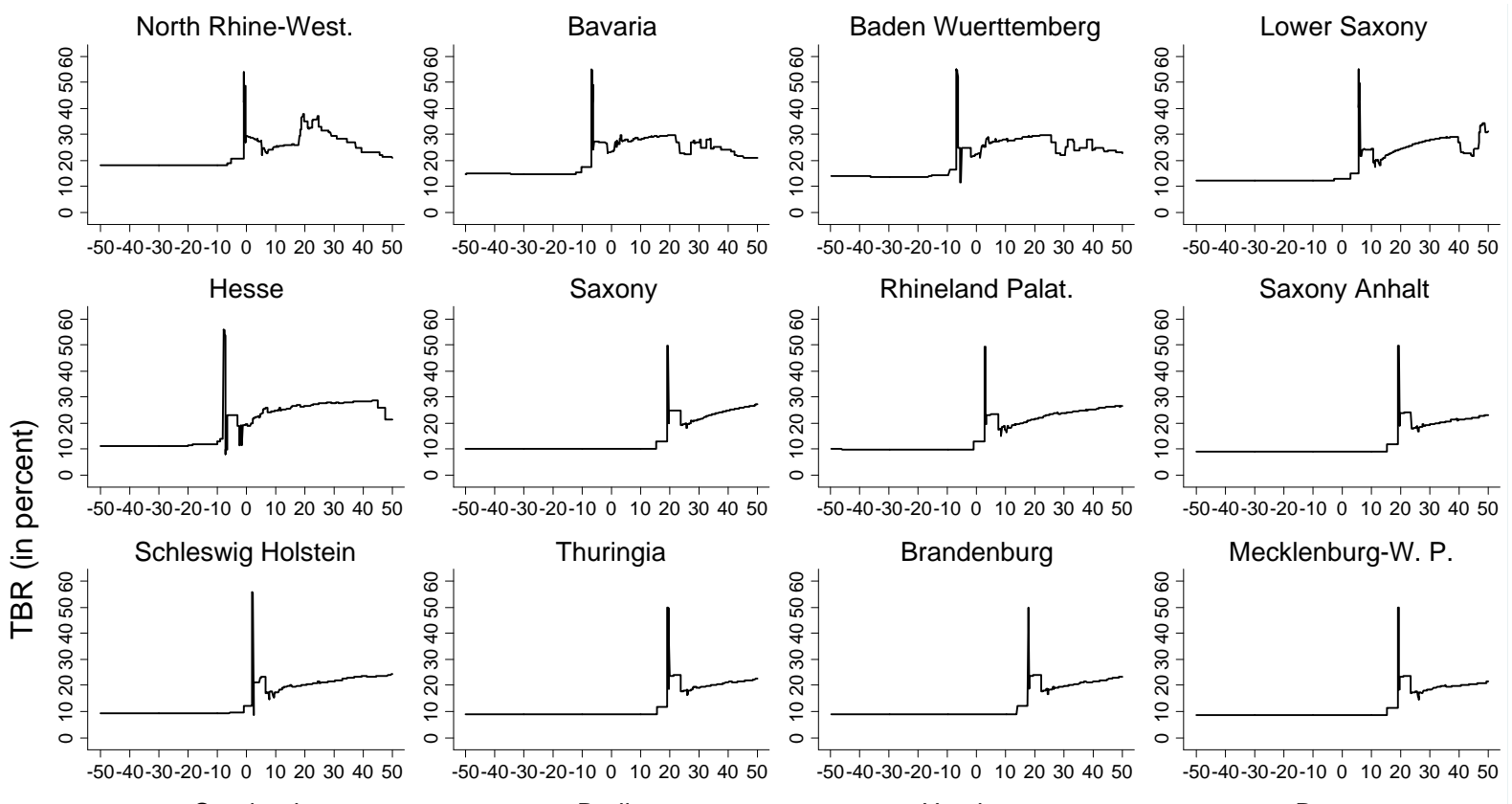

Mecklenburg-W. P.
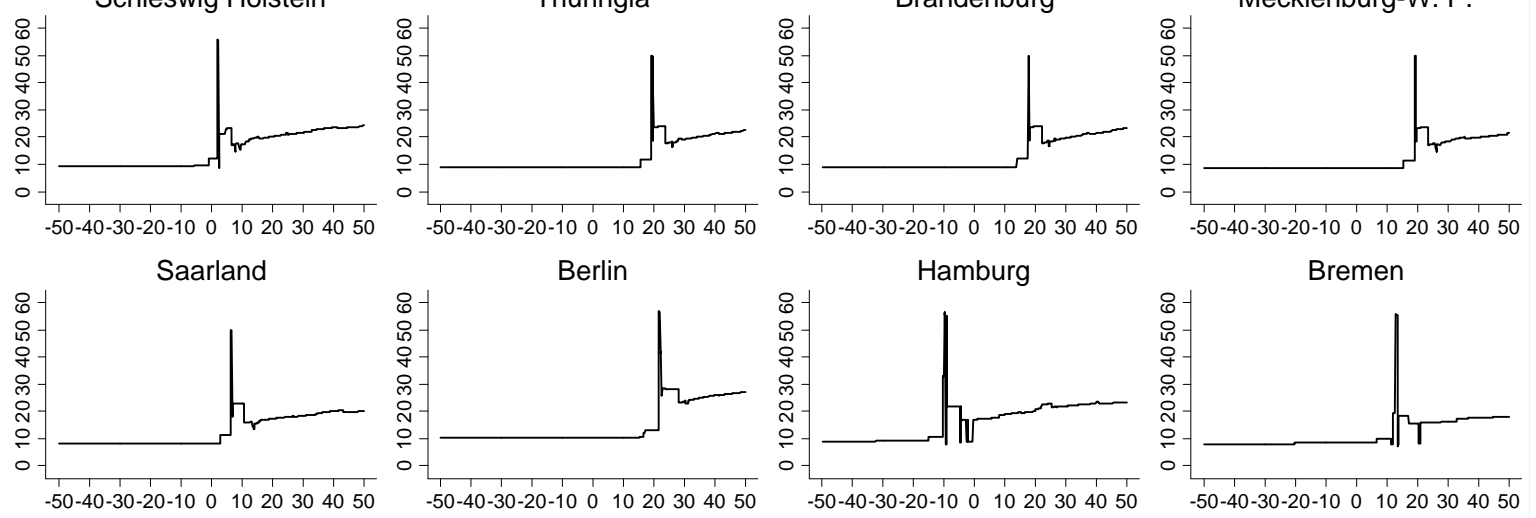
variation of income tax revenue per capita (in Euro)

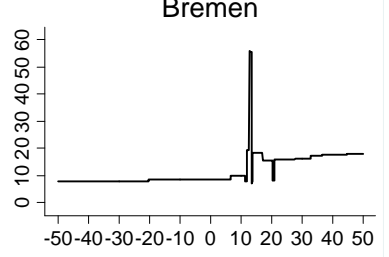

Note. Own computations. 
Figure 2a. Distributions of internalized marginal tax revenues (IMR) of an additional taxed Euro, 1998
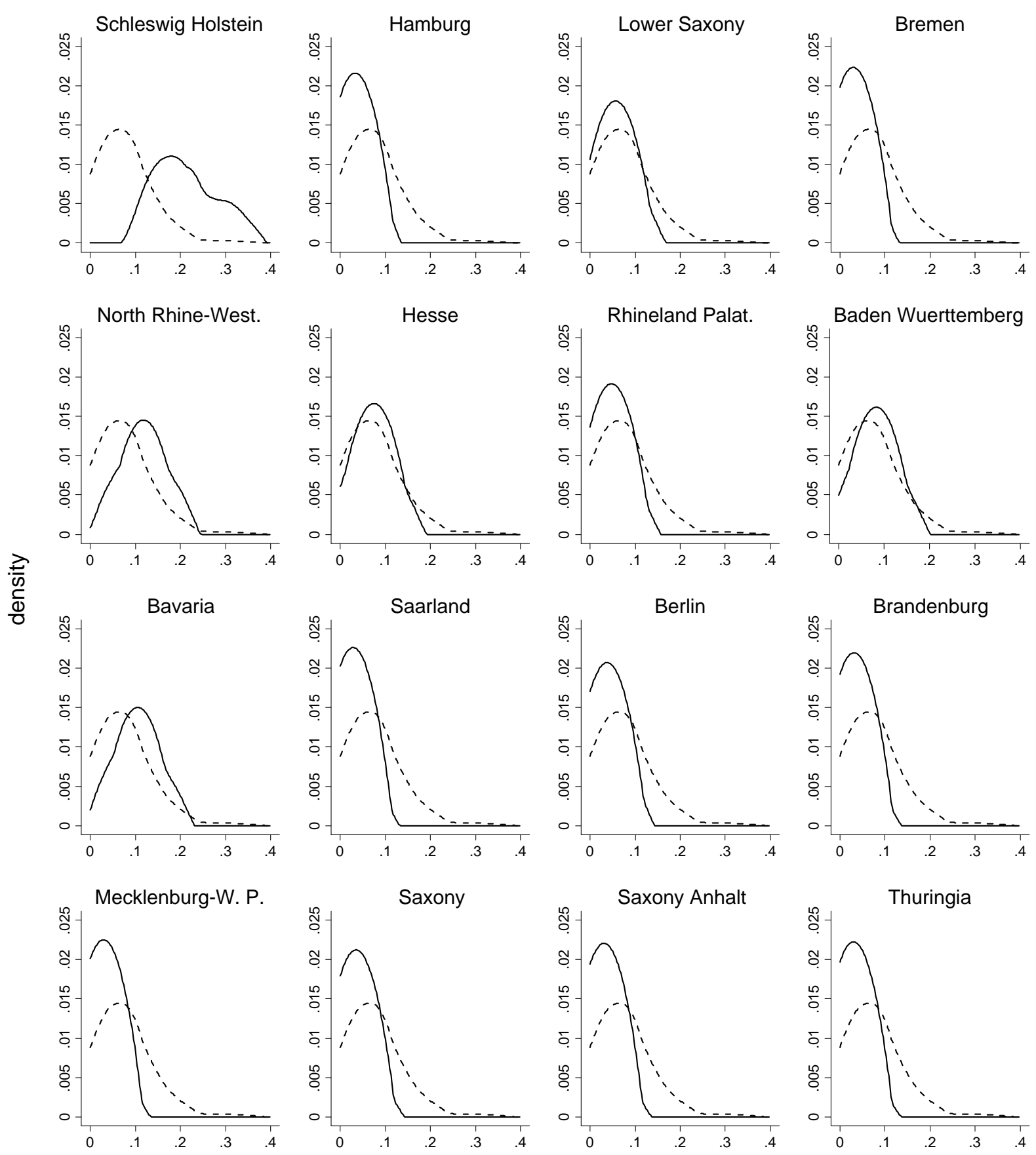

State

Germany

Note. Own computations. Data. FAST 1998. 
Figure 2b. Distributions of internalized marginal tax revenues (IMR) of an additional taxed Euro, 2001
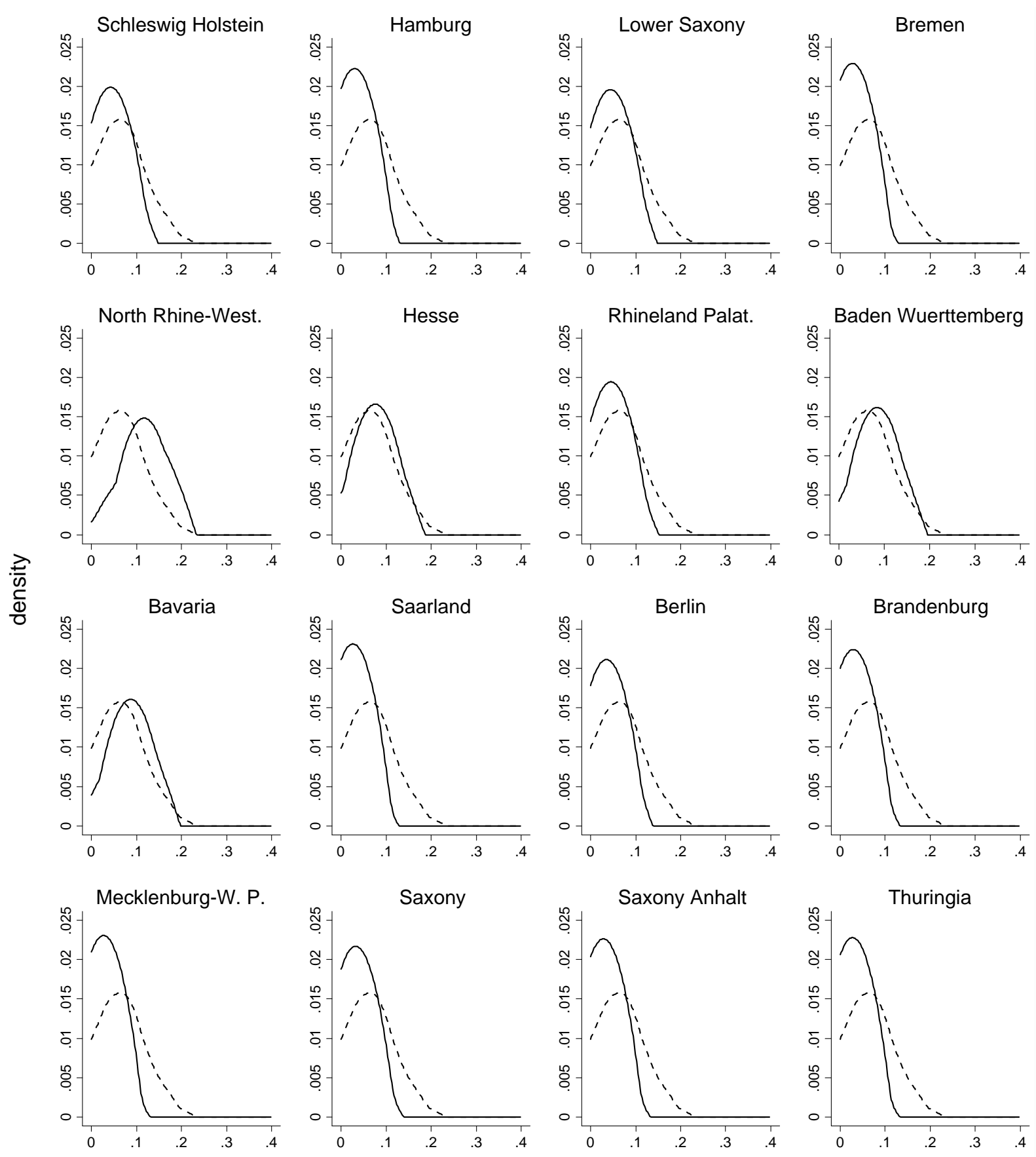

State

Germany

Note. Own computations. Data. FAST 2001. 
Figure 2c. Distributions of internalized marginal tax revenues (IMR) of an additional taxed Euro, 2004
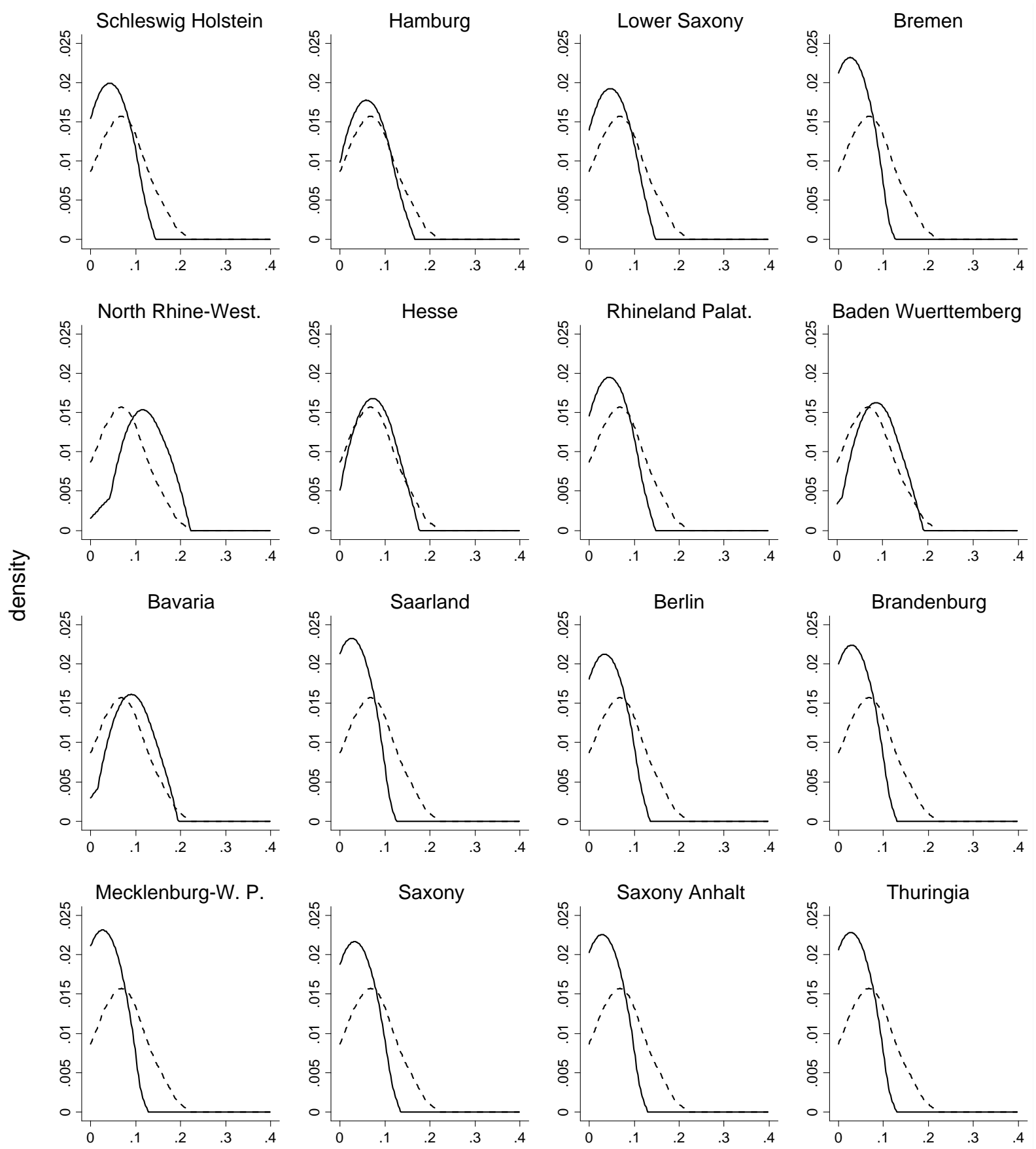

State

Germany

Note. Own computations. Data. FAST 2004. 


\section{Appendix}

Table A1. Sample statistics

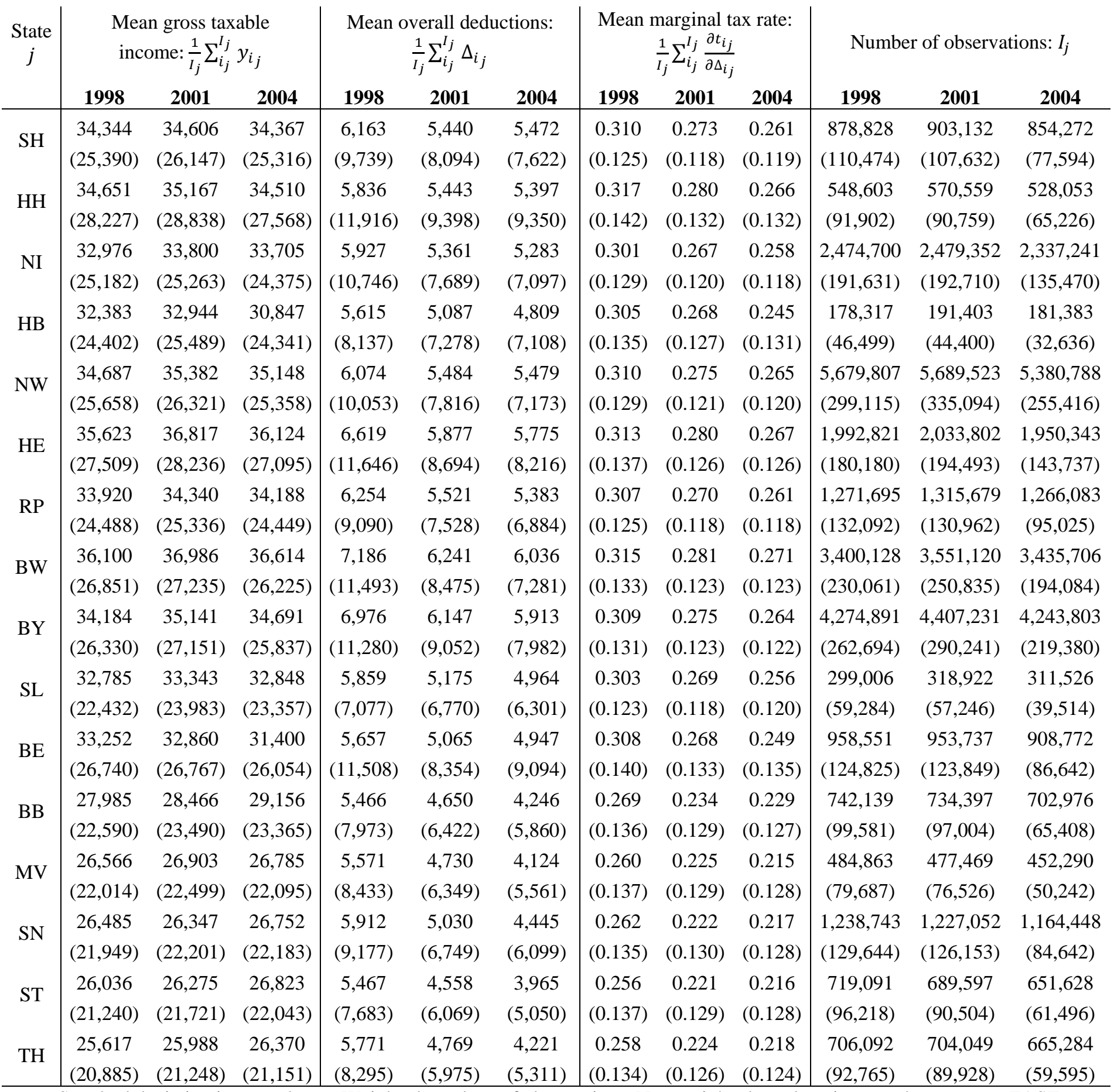

Note. Standard deviation in parentheses. Weighted numbers of observations. Non-weighted numbers in parentheses. Data. FAST 1998-2004. 
Table A2. State specific characteristics

\begin{tabular}{c|ccc|ccc|ccc} 
State & \multicolumn{2}{|c|}{ Staffing of financial administration } & \multicolumn{3}{|c|}{ Per capita GDP } & \multicolumn{3}{c}{ Population density (per km $\left.\mathbf{~}^{2}\right)$} \\
& 1998 & 2001 & 2004 & 1998 & 2001 & 2004 & 1998 & 2001 & 2004 \\
\hline BW & 208.76 & 232.11 & 284.07 & 32,023 & 33,406 & 32,805 & 291.62 & 296.51 & 299.77 \\
BY & 222.51 & 243.83 & 285.19 & 32,767 & 34,290 & 34,631 & 171.32 & 174.76 & 176.38 \\
BE & 110.51 & 120.63 & 152.22 & 27,171 & 26,569 & 25,178 & 3828.80 & 3817.09 & 3816.41 \\
BB & 172.05 & 188.95 & 246.748 & 19,288 & 20,273 & 20,667 & 87.86 & 87.95 & 87.09 \\
HB & 109.86 & 174.47 & 240.40 & 37,908 & 39,421 & 40,197 & 1593.28 & 1573.44 & 1581.94 \\
HH & 105.92 & 143.14 & 187.02 & 48,985 & 50,646 & 50,171 & 2251.30 & 2286.09 & 2297.30 \\
HE & 210.79 & 245.35 & 287.79 & 34,006 & 35,672 & 35,873 & 285.82 & 287.84 & 288.79 \\
MV & 164.04 & 179.73 & 230.15 & 19,189 & 19,931 & 20,344 & 77.56 & 75.89 & 74.15 \\
NI & 226.13 & 230.89 & 280.30 & 26,009 & 26,151 & 25,707 & 165.20 & 167.11 & 168.04 \\
NW & 213.12 & 227.86 & 275.25 & 29,212 & 29,274 & 29,364 & 527.26 & 529.51 & 530.19 \\
RP & 210.64 & 226.17 & 258.88 & 25,653 & 25,729 & 26,174 & 202.73 & 203.94 & 204.55 \\
SR & 188.18 & 170.46 & 237.93 & 26,275 & 26,983 & 27,743 & 418.19 & 415.17 & 411.26 \\
SN & 156.55 & 184.92 & 230.43 & 19,561 & 20,381 & 21,896 & 243.73 & 238.02 & 233.25 \\
ST & 182.47 & 191.38 & 222.32 & 18,726 & 19,511 & 20,775 & 130.78 & 126.19 & 121.98 \\
SH & 221.51 & 227.03 & 292.33 & 26,832 & 27,121 & 26,229 & 175.07 & 177.49 & 179.04 \\
TH & 157.60 & 177.55 & 222.87 & 18,610 & 19,771 & 20,830 & 152.28 & 149.10 & 145.63 \\
\hline
\end{tabular}

Note. Staffing of the financial administration is the total number of income tax returns divided by full time equivalent employees working in the state's financial administration. Per capita GDP is denoted in 2004 prices. Source: Federal Statistical Office. 
Table A3a. Sample statistics of treatment and control samples, Schleswig-Holstein

\begin{tabular}{|c|c|c|c|c|}
\hline & \multicolumn{4}{|c|}{ Mean of variable } \\
\hline & \multicolumn{2}{|c|}{ Treatment group } & \multicolumn{2}{|c|}{ Control group } \\
\hline & 2001 & 1998 & 2001 & 1998 \\
\hline \multicolumn{5}{|l|}{ Char } \\
\hline \multirow[t]{2}{*}{$y_{i}$} & 110,732 & 103,702 & 111,142 & 104,176 \\
\hline & $(30,482)$ & $(29,046)$ & $(30,237)$ & $(28,330)$ \\
\hline \multirow[t]{2}{*}{ married } & 0.658 & 0.658 & 0.658 & 0.658 \\
\hline & $(0.474)$ & $(0.474)$ & $(0.474)$ & $(0.474)$ \\
\hline \multirow[t]{2}{*}{ church } & 0.762 & 0.756 & 0.763 & 0.763 \\
\hline & $(0.426)$ & $(0.430)$ & $(0.425)$ & $(0.425)$ \\
\hline \multirow[t]{2}{*}{ children } & 1.017 & 1.013 & 1.015 & 1.015 \\
\hline & (1.114) & (1.109) & (1.109) & (1.115) \\
\hline \multirow[t]{2}{*}{ age } & 4.567 & 4.552 & 4.563 & 4.554 \\
\hline & (1.125) & (1.116) & (1.115) & $(1.122)$ \\
\hline \multicolumn{5}{|l|}{ Source } \\
\hline agriculture/ forestry & $\begin{array}{c}0.042 \\
(0.200)\end{array}$ & $\begin{array}{c}0.042 \\
(0.201)\end{array}$ & $\begin{array}{c}0.042 \\
(0.200)\end{array}$ & $\begin{array}{c}0.043 \\
(0.203)\end{array}$ \\
\hline business & $\begin{array}{c}0.289 \\
(0.453)\end{array}$ & $\begin{array}{c}0.283 \\
(0.450)\end{array}$ & $\begin{array}{c}0.292 \\
(0.45) 5\end{array}$ & $\begin{array}{c}0.293 \\
(0.455)\end{array}$ \\
\hline \multirow[t]{2}{*}{ self employment } & 0.295 & 0.299 & 0.294 & 0.298 \\
\hline & $(0.456)$ & $(0.458)$ & $(0.456)$ & $(0.457)$ \\
\hline \multirow[t]{2}{*}{ employment } & 0.727 & 0.728 & 0.724 & 0.725 \\
\hline & $(0.446)$ & $(0.445)$ & $(0.447)$ & $(0.447)$ \\
\hline \multirow[t]{2}{*}{ investment } & 0.357 & 0.357 & 0.359 & 0.356 \\
\hline & $(0.479)$ & $(0.479)$ & $(0.480)$ & $(0.479)$ \\
\hline \multirow[t]{2}{*}{ rent/lease } & 0.235 & 0.233 & 0.237 & 0.233 \\
\hline & $(0.424)$ & $(0.423)$ & $(0.425)$ & $(0.423)$ \\
\hline \multirow[t]{2}{*}{ other } & 0.118 & 0.118 & 0.119 & 0.119 \\
\hline & $(0.323)$ & $(0.323)$ & $(0.323)$ & $(0.324)$ \\
\hline
\end{tabular}

Note. Treatment group in 2001 is the base sample, treatment group 1998 and control groups in 2001and 1998 are matched to the base sample to resemble base sample characteristics. Standard deviation in parentheses.

Data. FAST 1998 and 2001. 
Table A3b. Sample statistics of treatment and control samples, Bavaria

\begin{tabular}{|c|c|c|c|c|}
\hline & \multicolumn{4}{|c|}{ Mean of variable } \\
\hline & \multicolumn{2}{|c|}{ Treatment group } & \multicolumn{2}{|c|}{ Control group } \\
\hline & 2001 & 1998 & 2001 & 1998 \\
\hline \multicolumn{5}{|l|}{ Char } \\
\hline \multirow[t]{2}{*}{$y_{i}$} & 115,982 & 108,823 & 116,918 & 109,151 \\
\hline & $(27,271)$ & $(26,102)$ & $(27,214)$ & $(25,603)$ \\
\hline \multirow[t]{2}{*}{ married } & 0.704 & 0.704 & 0.704 & 0.704 \\
\hline & $(0.456)$ & $(0.456)$ & $(0.456)$ & $(0.456)$ \\
\hline \multirow[t]{2}{*}{ church } & 0.864 & 0.864 & 0.864 & 0.864 \\
\hline & $(0.342)$ & $(0.342)$ & $(0.342)$ & $(0.343)$ \\
\hline \multirow[t]{2}{*}{ children } & 0.993 & 1.002 & 0.992 & 0.998 \\
\hline & (1.084) & (1.101) & (1.083) & (1.093) \\
\hline \multirow[t]{2}{*}{ age } & 4.412 & 4.417 & 4.414 & 4.412 \\
\hline & (1.109) & (1.105) & (1.094) & (1.105) \\
\hline \multicolumn{5}{|l|}{ Source } \\
\hline \multirow[t]{2}{*}{ agriculture/ forestry } & 0.021 & 0.021 & 0.021 & 0.021 \\
\hline & $(0.143)$ & $(0.142)$ & $(0.143)$ & $(0.144)$ \\
\hline \multirow[t]{2}{*}{ business } & 0.262 & 0.265 & 0.262 & 0.261 \\
\hline & $(0.439)$ & $(0.441)$ & $(0.440)$ & $(0.439)$ \\
\hline \multirow[t]{2}{*}{ self employment } & 0.274 & 0.274 & 0.274 & 0.273 \\
\hline & $(0.446)$ & $(0.446)$ & $(0.446)$ & $(0.446)$ \\
\hline \multirow[t]{2}{*}{ employment } & 0.798 & 0.796 & 0.797 & 0.796 \\
\hline & $(0.401)$ & $(0.403)$ & $(0.402)$ & $(0.403)$ \\
\hline \multirow[t]{2}{*}{ investment } & 0.394 & 0.396 & 0.394 & 0.397 \\
\hline & $(0.489)$ & $(0.489)$ & $(0.489)$ & $(0.489)$ \\
\hline \multirow[t]{2}{*}{ rent/lease } & 0.232 & 0.230 & 0.232 & 0.233 \\
\hline & $(0.422)$ & $(0.421)$ & $(0.422)$ & $(0.423)$ \\
\hline \multirow[t]{2}{*}{ other } & 0.104 & 0.105 & 0.103 & 0.106 \\
\hline & $(0.305)$ & $(0.307)$ & $(0.304)$ & $(0.308)$ \\
\hline
\end{tabular}

Note. Treatment group in 2001 is the base sample, treatment group 1998 and control groups in 2001and 1998 are matched to the base sample to resemble base sample characteristics. Standard deviation in parentheses.

Data. FAST 1998 and 2001. 
Table A3c. Sample statistics of treatment and control samples, Hamburg

\begin{tabular}{|c|c|c|c|c|}
\hline & \multicolumn{4}{|c|}{ Mean of variable } \\
\hline & \multicolumn{2}{|c|}{ Treatment group } & \multicolumn{2}{|c|}{ Control group } \\
\hline & 2004 & 2001 & 2004 & 2001 \\
\hline \multicolumn{5}{|l|}{ Char } \\
\hline \multirow[t]{2}{*}{$y_{i}$} & 105,480 & 107,189 & 103,873 & 107,035 \\
\hline & $(27,740)$ & $(30,199)$ & $(26,327)$ & $(29,755)$ \\
\hline \multirow[t]{2}{*}{ married } & 0.588 & 0.588 & 0.588 & 0.588 \\
\hline & $(0.492)$ & $(0.492)$ & $(0.492)$ & $(0.492)$ \\
\hline \multirow[t]{2}{*}{ church } & 0.593 & 0.594 & 0.589 & 0.589 \\
\hline & $(0.491)$ & $(0.491)$ & $(0.492)$ & $(0.492)$ \\
\hline \multirow[t]{2}{*}{ children } & 0.585 & 0.578 & 0.582 & 0.578 \\
\hline & $(0.933)$ & $(0.925)$ & $(0.929)$ & $(0.928)$ \\
\hline \multirow[t]{2}{*}{ age } & 4.475 & 4.479 & 4.486 & 4.495 \\
\hline & (1.149) & (1.161) & (1.204) & (1.309) \\
\hline \multicolumn{5}{|l|}{ Source } \\
\hline \multirow[t]{2}{*}{ agriculture/ forestry } & 0.004 & 0.003 & 0.004 & 0.004 \\
\hline & $(0.063)$ & $(0.05) 7$ & $(0.065)$ & $(0.062)$ \\
\hline \multirow[t]{2}{*}{ business } & 0.217 & 0.216 & 0.216 & 0.210 \\
\hline & $(0.412)$ & $(0.411)$ & $(0.412)$ & $(0.408)$ \\
\hline \multirow[t]{2}{*}{ self employment } & 0.278 & 0.280 & 0.280 & 0.280 \\
\hline & $(0.448)$ & $(0.449)$ & $(0.449)$ & $(0.449)$ \\
\hline \multirow[t]{2}{*}{ employment } & 0.768 & 0.766 & 0.771 & 0.773 \\
\hline & $(0.422)$ & $(0.424)$ & $(0.420)$ & $(0.419)$ \\
\hline \multirow[t]{2}{*}{ investment } & 0.311 & 0.311 & 0.312 & 0.316 \\
\hline & $(0.463)$ & $(0.463)$ & $(0.463)$ & $(0.465)$ \\
\hline \multirow[t]{2}{*}{ rent/lease } & 0.189 & 0.194 & 0.194 & 0.192 \\
\hline & $(0.391)$ & $(0.396)$ & $(0.395)$ & $(0.394)$ \\
\hline \multirow[t]{2}{*}{ other } & 0.137 & 0.136 & 0.134 & 0.136 \\
\hline & $(0.344)$ & $(0.343)$ & $(0.341)$ & $(0.343)$ \\
\hline
\end{tabular}

Note. Treatment group in 2004 is the base sample, treatment group 2001 and control groups in 2004 and 2001 are matched to the base sample to resemble base sample characteristics. Standard deviation in parentheses.

Data. FAST 2001 and 2004. 
Figure A1a. Distribution of Prospensity score for Schleswig-Holstein

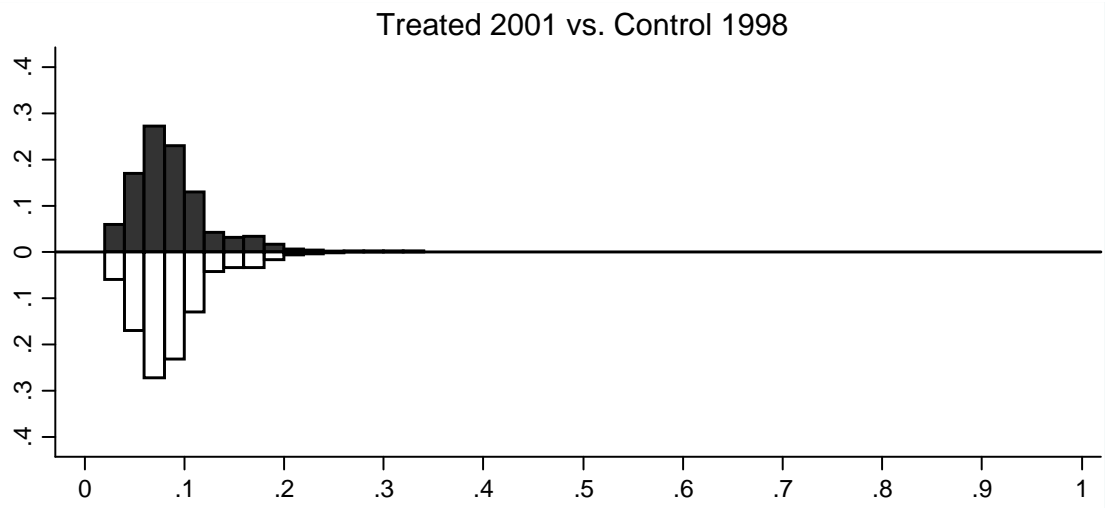

Treated 2001 vs. Control 2001
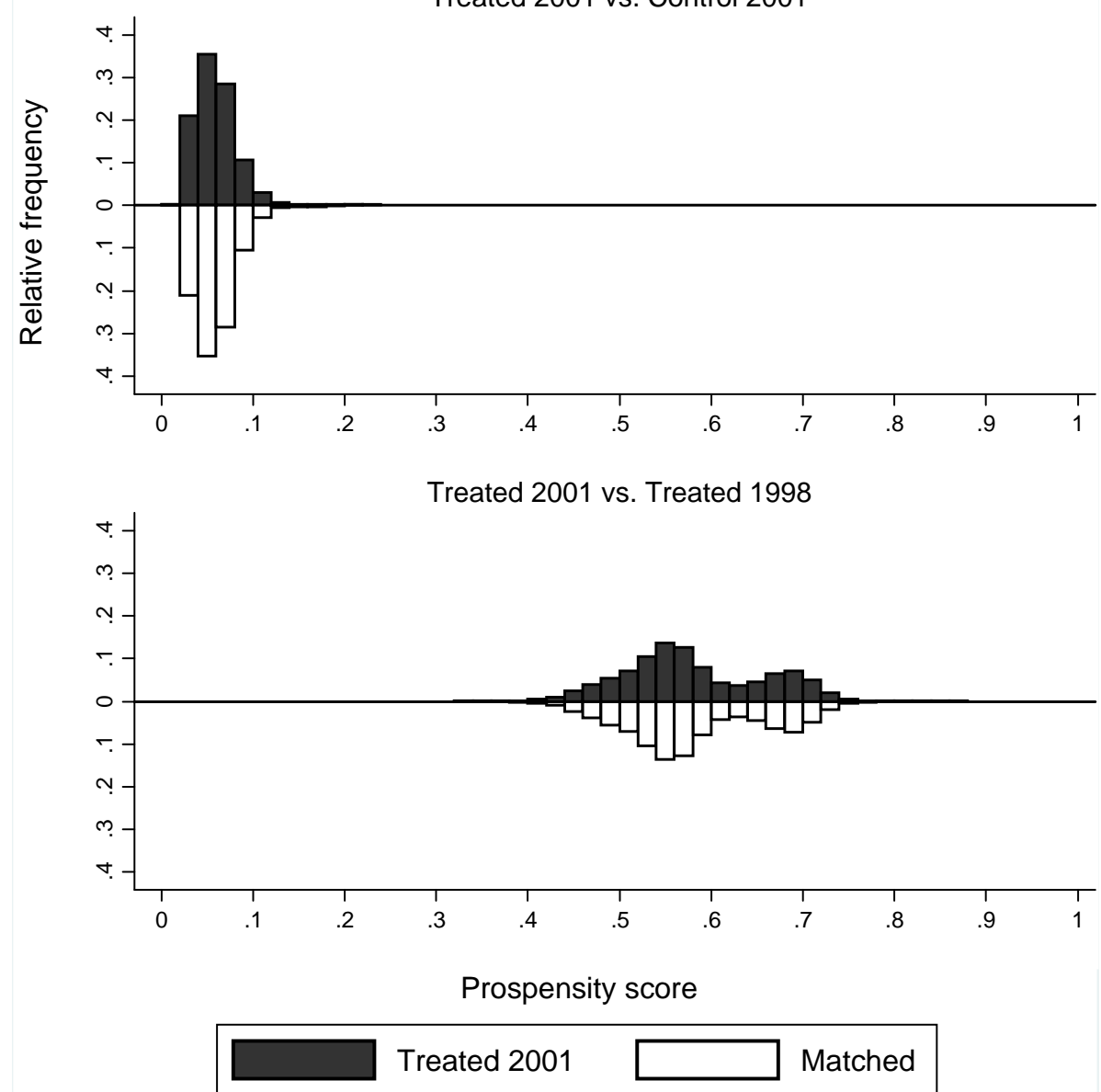

Note. Database is FAST 1998 and 2001. 
Figure A1b. Distribution of Prospensity score for Bavaria

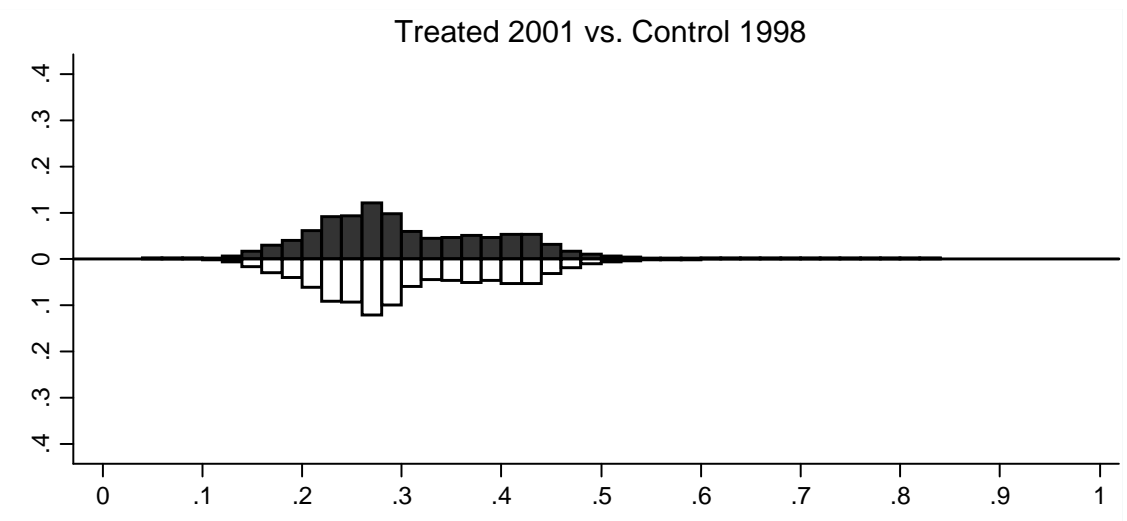

Treated 2001 vs. Control 2001

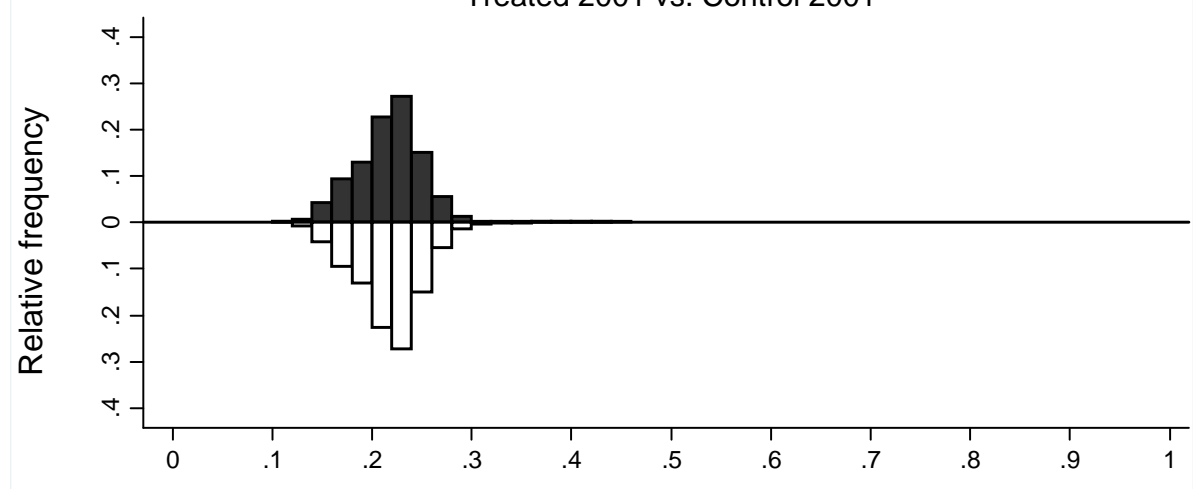

Treated 2001 vs. Treated 1998

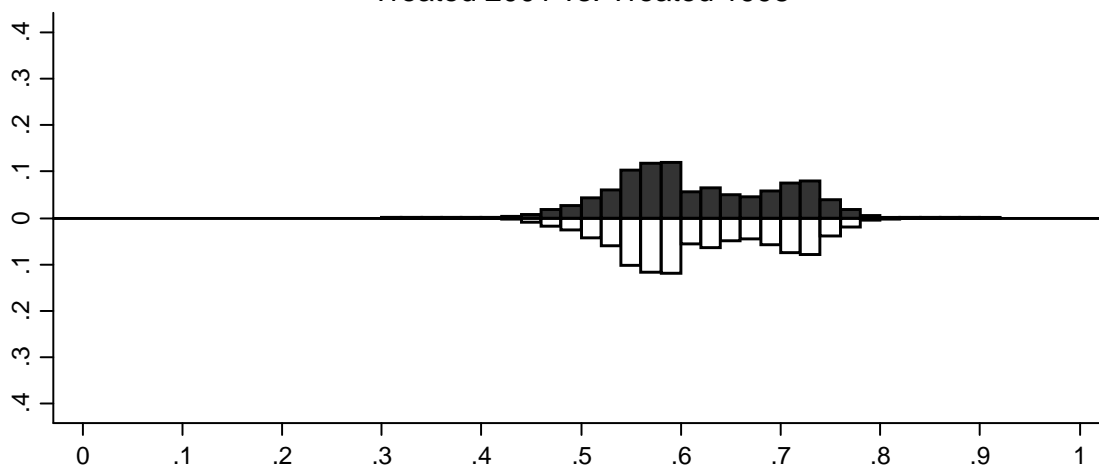

Prospensity score

Treated $2001 \quad \square$ Matched

Note. Database is FAST 1998 and 2001. 
Figure A1c. Distribution of Prospensity score for Hamburg

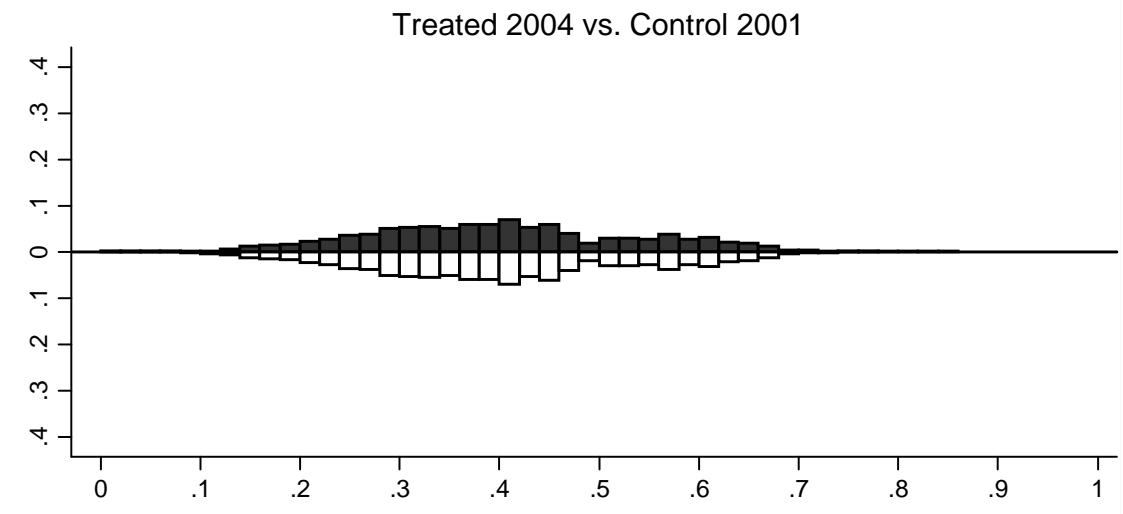

Treated 2004 vs. Control 2004

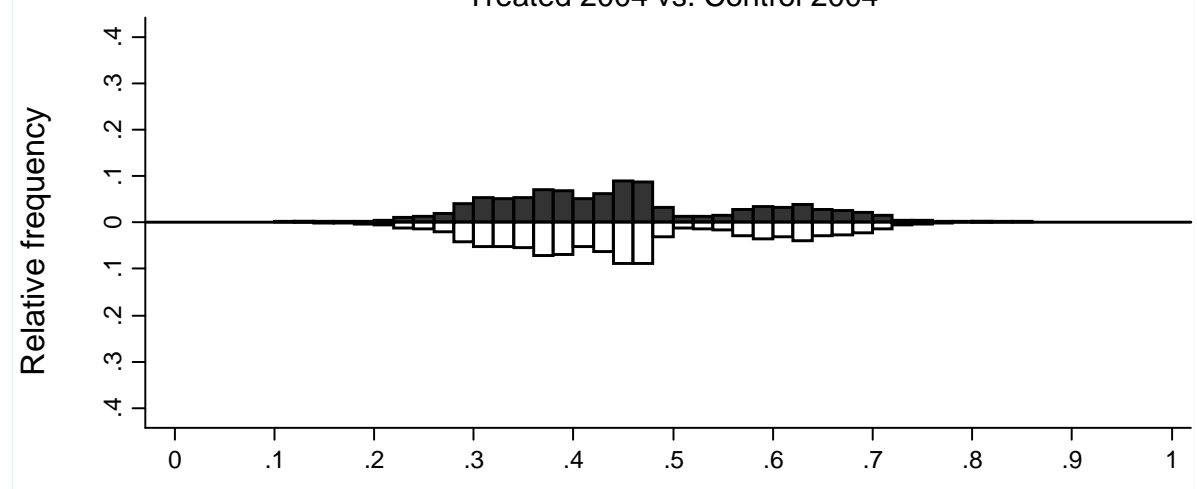

Treated 2004 vs. Treated 2001

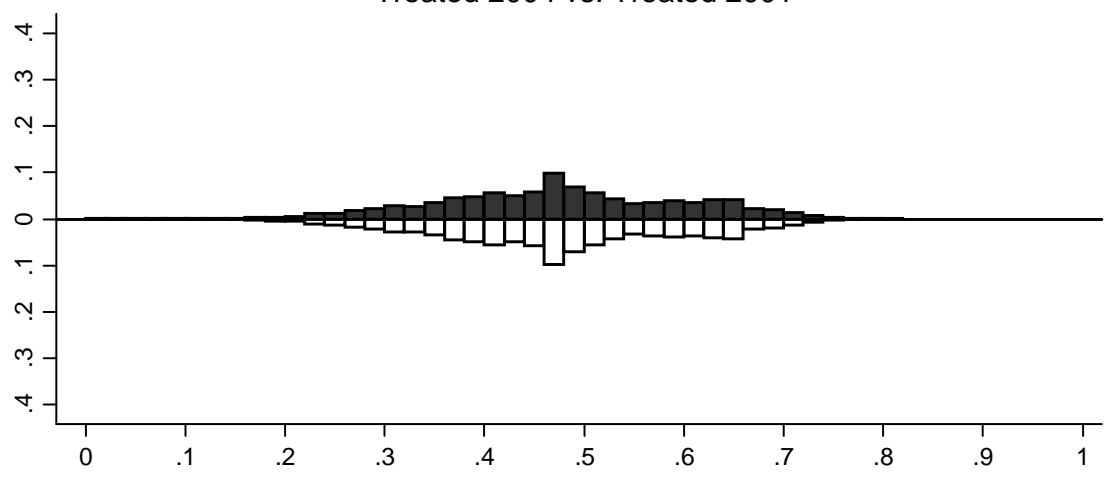

Prospensity score

Treated $2004 \quad \square$ Matched

Note. Database is FAST 2001 and 2004. 